\title{
Connexin35 Mediates Electrical Transmission at Mixed Synapses on Mauthner Cells
}

\author{
A. Pereda, ${ }^{1}$ J. O'Brien, ${ }^{2}$ J. I. Nagy, ${ }^{3}$ F. Bukauskas, ${ }^{1}$ K. G. V. Davidson, ${ }^{4}$ N. Kamasawa, ${ }^{4}$ T. Yasumura, ${ }^{4}$ and J. E. Rash ${ }^{4}$ \\ ${ }^{1}$ Department of Neuroscience, Albert Einstein College of Medicine, Bronx, New York 10461, 2Department of Ophthalmology and Visual Science, University \\ of Texas at Houston-Health Science Center, Houston, Texas 77030, 3. \\ ${ }^{4}$ Department of Biomedical Sciences, Colorado State University, Fort Collins, Colorado 80523
}

\begin{abstract}
Auditory afferents terminating as "large myelinated club endings" on goldfish Mauthner cells are identifiable "mixed" (electrical and chemical) synaptic terminals that offer the unique opportunity to correlate physiological properties with biochemical composition and specific ultrastructural features of individual synapses. By combining confocal microscopy and freeze-fracture replica immunogold labeling (FRIL), we demonstrate that gap junctions at these synapses contain connexin35 (Cx35). This connexin is the fish ortholog of the neuron-specific human and mouse connexin 36 that is reported to be widely distributed in mammalian brain and to be responsible for electrical coupling between many types of neurons. Similarly, connexin35 was found at gap junctions between neurons in other brain regions, suggesting that connexin35-mediated electrical transmission is common in goldfish brain. Conductance of gap junction channels at large myelinated club endings is known to be dynamically modulated by the activity of their colocalized glutamatergic synapses. We show evidence by confocal microscopy for the presence of the NR1 subunit of the NMDA glutamate receptor subtype, proposed to be a key regulatory element, at these large endings. Furthermore, we also show evidence by FRIL double-immunogold labeling that the NR1 subunit of the NMDA glutamate receptor is present at postsynaptic densities closely associated with gap junction plaques containing Cx35 at mixed synapses across the goldfish hindbrain. Given the widespread distribution of electrical synapses and glutamate receptors, our results suggest that the plastic properties observed at these identifiable junctions may apply to other electrical synapses, including those in mammalian brain.
\end{abstract}

Key words: gap junction; connexin36; electrical synapse; NMDA; synaptic plasticity; electrical coupling; auditory

\section{Introduction}

The cloning of connexin36 (Cx36), a novel neuron-specific gap junction protein in mice, has facilitated studies that indicate the existence of widespread electrical transmission in the mammalian CNS (Condorelli et al., 1998). In situ hybridization revealed that this connexin is widely distributed in mammalian CNS (Condorelli et al., 1998, 2000), and freeze-fracture replica immunogold labeling (FRIL) confirmed that Cx36 is restricted to neuronal gap junctions (Rash et al., 2001; Nagy et al., 2003). Accordingly, electrical coupling observed in cortical and thalamic interneurons (Galarreta and Hestrin, 1999; Gibson et al., 1999; Landisman et al., 2002) was nearly absent in Cx36 knock-out mice (Deans et al., 2001; Hormuzdi et al., 2001; Landisman et al.,

\footnotetext{
Received Sept. 10, 2002; revised June 19, 2003; accepted June 24, 2003.

This work was supported by National Institutes of Health Grants DC03186 (A.P.), EY 12857 (J.0.), and NS44010/ NS39040/NS44395 (J.E.R.) and the Canadian Institute of Health Research of Canada (J.I.N.). We thank R. Rodriguez, A. Bukauskiene C. Castillo, and M. Smith for immunochemical work; S. Curti for his contribution to the intracranial simultaneous recordings; B. Nicholson for providing the Cx43 Rebecca antibody, and I. Fischer for help with its Western blot; and R. Dunn and L. Maler for providing the AptNR1 antibody. We also thank P. Castillo, D. S. Spray, F.E. Dudek and M. V. L. Bennett for critically reading this manuscript. We are particularly indebted to M. Cammer and the Analytical Image Facility at the Albert Einstein College of Medicine for outstanding confocal microscopy assistance. We also thank D. Pettit for confocal assistance and B. Magnie for assistance with Photoshop images.

Correspondence should be addressed to A. Pereda, Department of Neuroscience, Albert Einstein College of Medicine, 1300 Morris Park Avenue, Bronx, NY 10465. E-mail: apereda@aecom.yu.edu. Copyright $\odot 2003$ Society for Neuroscience $\quad$ 0270-6474/03/237489-15\$15.00/0
}

2002). Likewise, cortical gamma oscillations $(30-80 \mathrm{~Hz})$, which are thought to be essential for cognitive processing, were impaired in Cx36 knock-out mice, suggesting that electrical synapses containing $\mathrm{Cx} 36$ are essential for the generation of synchronous activity (Deans et al., 2001; Hormuzdi et al., 2001).

Because of limited experimental accessibility, very little is known about the plastic properties of electrical synapses in mammals. In contrast, anatomically and physiologically identifiable auditory afferents terminating as large myelinated club endings on the lateral dendrite of the goldfish Mauthner cell (Bartelmez, 1915; Bodian, 1937) historically have constituted a powerful system to study the nature and properties of electrical transmission between neurons in vertebrates. Early electron microscope images of these terminals (Robertson et al., 1963) revealed zones of close membrane apposition having distinct hexagonal substructures that were later named gap junctions (Revel and Karnovsky, 1967; for review, see Bennett, 1977). The synaptic potentials evoked by these terminals provided early physiological evidence for the existence of electrical transmission in vertebrates (Bennett et al., 1963; Furshpan, 1964). Both gap junctional and glutamatergic synaptic transmission occur at these terminals (Nakajima, 1974; Tuttle et al., 1986), thus providing an ideal model to study interactions between these modalities of synaptic transmission.

A wealth of experimental evidence has shown that gap junctional conductance at large myelinated club endings is enhanced 
by sustained afferent activity (Yang et al., 1990; Pereda and Faber, 1996; Pereda et al., 1998). Because this enhancement requires NMDA receptor activation (Yang et al., 1990), it has been suggested that the observed activity-dependent modification of electrical synapses depends on functional interaction with their colocalized glutamatergic synapses (Pereda and Faber, 1996; Pereda et al., 1998). Given the widespread distribution of both glutamate receptors and gap junctions in vertebrate CNS, such functional interaction may constitute a common property of electrical synapses.

An essential step toward investigation of this possibility is to identify which member(s) of the multigene family of gap junction-forming proteins (connexins) is responsible for electrical transmission at large myelinated club endings. By combining confocal microscopy, electrophysiological recording, and FRIL analysis of individual Mauthner cells, we provide evidence that Cx35 (O'Brien et al., 1996, 1998), the fish counterpart of mammalian $\mathrm{Cx} 36$, mediates electrical transmission at gap junctions formed by these terminals. Consistent with the proposed regulatory hypothesis, postsynaptic specializations closely associated with gap junctions were found to contain NMDA receptors. Furthermore, this association was also found in other Cx35mediated mixed synapses, which are widely distributed in goldfish hindbrain.

\section{Materials and Methods}

Electrophysiological techniques. Intracellular recordings were obtained in vivo from nine VIIth nerve afferents, with recording sites in the root or intracranially, while simultaneous measurements were taken from the Mauthner cell lateral dendrite. Presynaptic recording electrodes were filled with a $2.5 \mathrm{M} \mathrm{KCl}$ solution, and their resistances were 35 and $45 \mathrm{M} \Omega$. A second electrode $(2.5 \mathrm{M} \mathrm{KCl}, 4-12 \mathrm{M} \Omega$ ) was inserted into the Mauthner cell lateral dendrite, 350-400 $\mu \mathrm{m}$ from the axon cap. For experiments in which recorded afferents or Mauthner cells were identified anatomically, electrodes were filled with a $4 \%$ solution of Neurobiotin in $2.5 \mathrm{M} \mathrm{KCl}$ (Vector Laboratories), and this solution was iontophoretically injected ( $400 \mathrm{msec}$ pulses of $50 \mathrm{nA}$ for $20 \mathrm{~min}$ ). In some experiments a $5 \%$ solution of Lucifer yellow carbohydrazide, lithium salt; Molecular Probes) in distilled water was iontophoretically injected into Mauthner cell somata.

Immunochemistry and confocal microscopy. Fish were perfused intracardially with $4 \%$ formaldehyde in phosphate buffer $(0.12 \mathrm{M}$ at $\mathrm{pH} 7.4)$ for 15 min, kept overnight in PBS, and sectioned with a Vibratome (20-50 $\mu \mathrm{m})$. Sections were rinsed several times with PBS, incubated overnight with anti-Cx36 (Ab298; 1:1000/5000), anti-Cx43 (1:200/2000), or antiCx35 (Chemicon MAB3045; 1:200/2000), rinsed in PBS, incubated for 2 hr with Texas Red-conjugated secondary antibody, and rinsed with PBS (antibodies described below). In experiments in which either afferents or Mauthner cells were injected with Neurobiotin, sections were also incubated for $1 \mathrm{hr}$ in streptavidin-conjugated FITC (dilution 1:200) in PBS. The sections were mounted on slides, dehydrated, cleared, covered, and examined under transmitted light or using fluorescence (Leitz Aristoplan) and confocal (Bio-Rad Radiance 2000 laser scanning confocal microscope) microscopes. Control sections were incubated with secondary antibodies in the absence of primary antibodies.

Western blotting and antibodies. For Western blots of tissues, crude goldfish plasma membranes were prepared by differential centrifugation of fresh tissue homogenates of retina and of small portions of goldfish hindbrain containing both of its Mauthner cells. This area ( $\sim 90 \mathrm{mg}$ of tissue) corresponds to the portion of goldfish hindbrain located below the cerebellum and is delimited by the anterior and posterior aspects of the cerebellar peduncles. Tissues were suspended in a solution containing $0.32 \mathrm{M}$ sucrose, $10 \mathrm{~mm}$ Tris-Cl, pH 7.4, $2 \mathrm{~mm}$ EGTA, and $5 \mathrm{~mm} \mathrm{MgCl}_{2}$ plus $1 \%(\mathrm{v} / \mathrm{v})$ protease inhibitor mixture (Sigma, St. Louis, MO), and homogenized by sonication for $30 \mathrm{sec}$ with a Branson Sonifier at 35\% power. Homogenates were centrifuged $10 \mathrm{~min}$ at $1000 \times g$, and the supernatant was collected and centrifuged for $1 \mathrm{hr}$ at $100,000 \times g$. The resulting membrane pellets were suspended in homogenization buffer plus $0.5 \%$ Nonidet P-40. Protein was assayed by the Bradford technique (Bio-Rad protein assay).

Forty microgram aliquots of membrane protein were dissolved in reducing SDS sample buffer and resolved on 10\% SDS-PAGE gels for immunoblots of NR1 or on $12 \%$ gels for immunoblots of connexins. Proteins were transferred at $18 \mathrm{~V}$ overnight to nitrocellulose membranes for probing of NR1, Cx36, and Cx43 or to polyvinylidenedifluoride membranes for probing of Cx35. Blots were blocked with 5\% Carnation nonfat dry milk in TBST ( $135 \mathrm{~mm} \mathrm{NaCl}, 3 \mathrm{~mm} \mathrm{KCl}, 25 \mathrm{~mm}$ Tris-Cl, pH 7.4, $0.05 \%$ Tween 20 ) for $1 \mathrm{hr}$ at room temperature. Primary antibody incubations and washes of membranes were conducted under several different conditions. Mouse anti-NR1 (B-D PharMingen 556308) was diluted to $0.5 \mu \mathrm{g} / \mathrm{ml}$ in TBST plus $5 \%$ milk and incubated for $2 \mathrm{hr}$ at room temperature. Mouse anti-Cx35 (Chemicon MAB3045) was diluted to 0.7 $\mu \mathrm{g} / \mathrm{ml}$ in hsTBST (500 mм NaCl, $3 \mathrm{~mm} \mathrm{KCl,} 25 \mathrm{~mm}$ Tris-Cl, pH 7.4, $0.05 \%$ Tween 20 ) plus $3 \%$ nonfat dry milk and incubated for $14 \mathrm{hr}$ at $4^{\circ} \mathrm{C}$. Rabbit anti-Cx36 (Ab298) was diluted to $0.7 \mu \mathrm{g} / \mathrm{ml}$ in TBST plus $3 \%$ nonfat dry milk and incubated for $14 \mathrm{hr}$ at room temperature. Mouse anti-Cx43 (Chemicon MAB3068) was diluted to $0.8 \mu \mathrm{g} / \mathrm{ml}$ in isTBST (320 mm NaCl, 3 mu KCl, 25 mm Tris-Cl, pH 7.4, 0.05\% Tween 20) plus $2 \%$ nonfat dry milk and $1 \%$ BSA and incubated for $14 \mathrm{hr}$ at $4^{\circ} \mathrm{C}$. Blots were washed at room temperature with a TBST solution corresponding to that used for the primary antibody. Washed blots were probed with the appropriate multiple-labeling grade peroxidase-conjugated $\mathrm{FAb}_{2}$ secondary antibodies (Jackson ImmunoResearch) at dilutions from 1:2500-1:5000 with the same blocking agent used for the primary antibody. Washes were done as for the primary antibodies. Bands were detected by chemiluminescence (Pierce SuperSignal). Western blots for a second Cx43 antibody (designated Rebecca, rabbit polyclonal, amino acid sequence 302-319; courtesy of Dr. B. Nicholson, University at Buffalo, Buffalo, NY) were similarly generated using total goldfish brain homogenates.

Freeze-fracture replica immunogold labeling. Both of the two Mauthner cells in each of five goldfish hindbrains were injected with Lucifer yellow and fixed by perfusion after the procedure described above. Brains were dissected and sliced into 150 - to $750-\mu \mathrm{m}$-thick sections and photographed before FRIL using a Molecular Dynamics Multiprobe 2001 inverted confocal microscope. All thicker slices were resectioned to a uniform $150 \mu \mathrm{m}$ thickness, infiltrated with $30 \%$ glycerol as cryoprotectant to minimize damage during freezing, and frozen by pneumatically damped contact against a liquid nitrogencooled copper block (Philips and Boyne, 1984). Samples were freeze fractured and replicated in a JEOL/RMC RFD 9010C freeze-fracture device, removed, and while still frozen, embedded in Lexan plastic film on a gold "index" grid. Samples were thawed, photography mapped by confocal microscopy, and cleaned by vigorous washing for $24-29 \mathrm{hr}$ in $2.5 \%$ SDS detergent (Fujimoto, 1995; as modified in Rash and Yasumura, 1999). Replicas were labeled with the following combinations of primary and secondary antibodies: rabbit polyclonal antibodies to Cx36 (Ab298) and a commercially available antibody (Zymed 51-6300); monoclonal anti-Cx35 (Chemicon MAB3045); and monoclonal antibodies to Cx43 (Chemicon MAB3068) and glutamate receptor NR1 (B-D PharMingen 556308). Goat anti-rabbit gold-conjugated secondary antibodies were from Chemicon (10, 20 $\mathrm{nm})$, Jackson Immunoresearch $(6,12,18 \mathrm{~nm})$, and BBInternational (Cardiff, UK) (5, 10-nm). Goat anti-mouse secondary antibodies were from Chemicon $(10,20 \mathrm{~nm})$ and Jackson Immunoresearch $(6$, $12,18 \mathrm{~nm}$ ). The FRIL methods used in this study are similar to those reported previously (Rash and Yasumura, 1999; Rash et al., 2001; as modified from Fujimoto, 1995). FRIL replicas were examined in a JEOL 2000 EX-II transmission electron microscopy or a JEOL 1200 EX, both operated at $100 \mathrm{kV}$ and photographed as stereo pairs with an included angle of $8^{\circ}$. Using the coordinates from the index grids, FRIL images were directly correlated with the corresponding confocal photo maps. 


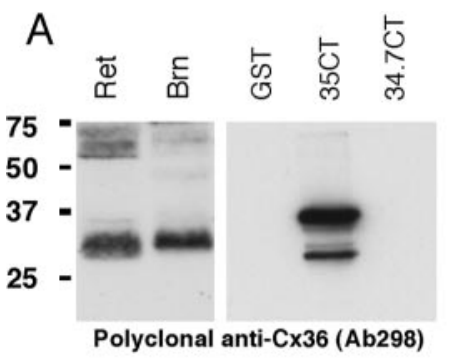

B
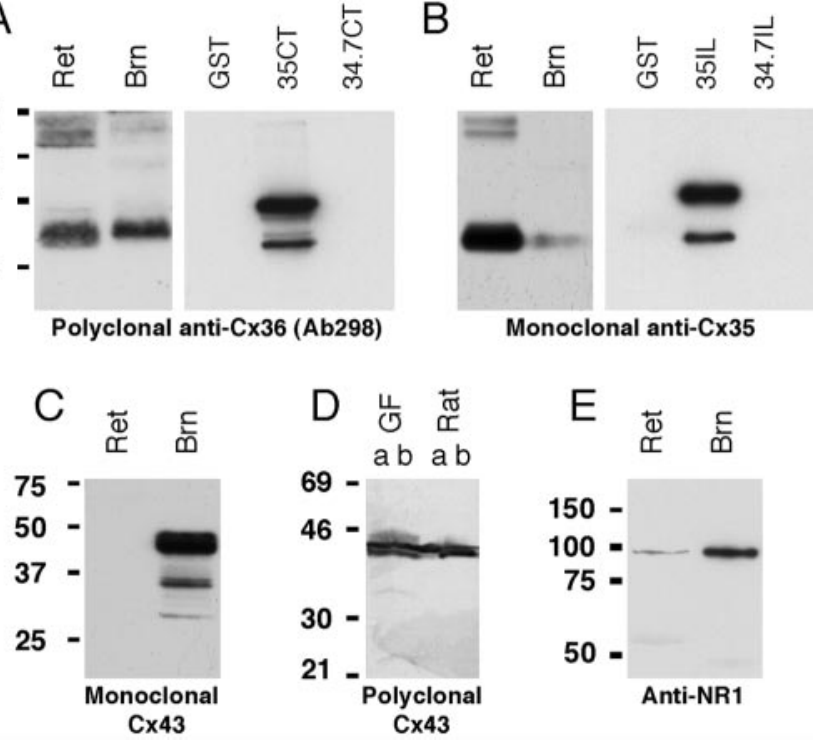

Figure 1. Western blot analyses with various anti-connexin and anti-glutamate receptor antibodies. A, Polyclonal anti-Cx36 Ab298 recognizes a complex of bands at 31-33 kDa in goldfish retina (Ret) and hindbrain (Brn) and bands at $60-70 \mathrm{kDa}$ possibly representing a dimer form of Cx35 (left). In bacterial extracts (right), Ab298 detects the $36 \mathrm{kDa}$ Cx35 C-terminal GST fusion protein (35CT) and its lower molecular weight cleavage products, but not $\mathrm{C} \times 34.7$ C-terminal fusion protein (34.7CT) or GST alone. B, Monoclonal anti-Cx35 also detects the $31-33 \mathrm{kDa}$ bands in hindbrain and retina (left). In crude bacterial extracts (right), only the $\mathrm{Cx} 35$ intracellular loop GST fusion protein is recognized. C, D, Both monoclonal ( $C$ and polyclonal $(D)$ anti-Cx43 antibodies recognize two to three prominent bands at $40-44 \mathrm{kDa}$ in goldfish hindbrain. These bands comigrate with $\mathrm{C} \times 43$ from rat brain $(D)$, and both membranes (lanes a) and supernatant fractions (lanes b) contain Cx43. E, Monoclonal anti-NR1 recognizes a single 100 $\mathrm{kDa}$ band in retina and hindbrain.

\section{Results}

\section{Specificity of antibodies}

Two antibodies were used to label Cx35 in goldfish. As reported previously (Rash et al., 2000), antibody Ab298 was generated in rabbits immunized with a synthetic peptide corresponding to amino acids $298-318$ in the mouse Cx36 sequence and then affinity purified. Ab298 was shown to detect mouse Cx36 in various brain regions by Western blotting and to label gap junctions between neurons by FRIL (Rash et al., 2000, 2001). The mouse Cx36 peptide sequence (Condorelli et al., 1998; Sohl et al., 1998) against which it was generated (RNKDLPRVSVPNFGRTQSSDS) contains considerable homology with amino acids 277-298 (RNKDSPHRIGVPNFGRTQSSDS) in the perch Cx35 sequence (O’Brien et al., 1998), differing by only a few amino acids. In contrast, these sequences differ substantially from a corresponding sequence in the closely related perch Cx34.7 (O'Brien et al., 1998), with which Ab298 would be expected to show no crossreaction (see below).

Monoclonal anti-Cx35 (Chemicon MAB3045) was generated against a recombinant fusion protein containing the entire intracellular loop of perch Cx35. The specificities of both polyclonal Ab298 and monoclonal anti-Cx35 were confirmed with Western blots of recombinant perch $\mathrm{Cx} 35$ and $\mathrm{Cx} 34.7$ proteins (Fig. $1 A, B)$. The glutathione $S$-transferase (GST) fusion proteins used were generated by cloning the intracellular loop and C-terminal tail coding sequences of perch $\mathrm{Cx} 35$ and perch Cx34.7 into pET42 (J. O'Brien, unpublished results). The constructs were expressed in Escherichia coli strain BL21(DE3), and Western blots were performed on crude lysates of cells after $1 \mathrm{hr}$ of induction. Approximately $0.5 \mu \mathrm{g}$ of total protein was loaded per lane. Figure 1, A and $B$, shows that both antibodies were specific for $\mathrm{Cx} 35$ and did not recognize the corresponding portion of Cx34.7.

All of the antibodies used in this study labeled appropriate bands in Western blots of goldfish tissues (Fig. 1). Both Ab298 and MAB3045 recognized the same bands in goldfish hindbrain and retina. Because these antibodies recognize epitopes in different cytoplasmic domains of $\mathrm{Cx} 35$, this provides further evidence that antibody labeling was specific. The monoclonal anti-NR1 used for FRIL immunolabeling (B-D PharMingen 556308) recognized a single $100 \mathrm{kDa}$ band in retina and hindbrain. A second antibody directed against the NR1 subunit of the NMDA receptor of the electric fish Apteronotus (AptNR1; polyclonal; amino acid sequence 844-901) was used for light microscopic immunolabeling. Previous immunoblotting demonstrated the specificity of this antibody for teleost NMDA-NR1 (Berman et al., 2001). Both monoclonal and polyclonal anti-Cx43 antibodies recognize two to three prominent bands at $40-44 \mathrm{kDa}$ in goldfish hindbrain (Fig. $1 C, D$ ).

\section{Identification of large myelinated club endings}

Mauthner cells were intracellularly injected with either Neurobiotin or Lucifer yellow to facilitate cell identification during confocal analysis and FRIL investigations. Figure $2 \mathrm{~A}$ illustrates one of these cells injected with Lucifer yellow, allowing visualization of its most relevant portions. The large myelinated club endings, henceforth referred to as club endings, constitute a special type of auditory afferent terminating as unramified, single terminals on distal portions of the lateral dendrite (Bartelmez, 1915; Bodian, 1937). Morphologically, these contacts comprise a relatively homogeneous group of terminals having ultrastructural features typical of chemical transmission coexisting with gap junctions (Nakajima, 1974; Tuttle et al., 1986). Consistent with the presence of gap junctions between these elements, the large afferent fibers giving rise to club endings were shown to be dye-coupled to Mauthner cells (Pereda et al., 1995) and were detected after Neurobiotin-transfer from Mauthner cells to club ending (Fig. $2 B$ ). Club endings are seen on the surface of the lateral dendrite under Nomarski optics (Fig. 2C) (Tuttle et al., 1986).

Club endings have characteristic physiological properties, allowing correlation of physiology with ultrastructural features of chemical and gap junctional transmission at these contacts. Presynaptic action potentials at these terminals evoke mixed excitatory synaptic responses in the lateral dendrite. These responses are composed of a fast electrical potential followed by a chemical EPSP mediated by glutamate (Furshpan, 1964; Lin and Faber, 1988; Wolszon et al., 1997), as demonstrated previously by simultaneous recordings from single auditory afferents in the nerve root and a Mauthner cell lateral dendrite (Lin and Faber, 1988). However, detection of subthreshold responses across these electrical synapses is difficult because of electrotonic attenuation of these signals along the afferents. To examine more directly the properties of these electrical synapses, we performed intracranial recordings simultaneously from Mauthner cells and club endings $(n=5)$. One such recording is illustrated in Figure 2, $D$ and $E$, where the presynaptic intraterminal electrode was at a distance of $100-150 \mu \mathrm{m}$ from the postsynaptic electrode that had been inserted into the distal portion of a Mauthner cell lateral dendrite (Fig. 2D). As observed in Figure 2E, the electrical component of the postsynaptic potential recorded in the dendrite combines the time course of the depolarization produced by presynaptic pulse current injection and the presynaptic spike evoked by this depolarizing pulse. In addition, and not detected presynaptically, a slower response follows the coupling potential of the presynaptic 
spike corresponding to the activation of glutamate receptors after the release of glutamate from the recorded terminal (Fig. 2E, chemical).

\section{Confocal microscopy revealed abundant} Cx35 at large myelinated club endings

To determine whether $\mathrm{Cx} 35$ is present at club endings, we performed experiments using a previously characterized anti-Cx36 antibody (Rash et al., 2001) for immunofluorescence labeling of Mauthner cells that had been injected with Neurobiotin during physiological recordings $(n=7)$. Along the distal portion of the lateral dendrite, immunofluorescence was observed at large ovoid areas presumed to correspond to club endings because of their size and location. The contact area of each club ending was delineated by multiple fluorescent patches clearly identifiable in confocal projections (Fig. 3A), consistent with ultrastructural data describing the presence of up to 200 gap junction plaques at individual club endings (Tuttle et al., 1986). The pattern of labeling in these patches was more evident when a few confocal z-sections were averaged (Fig. 3B). The overall size and shape of the labeled terminals is consistent with that of club endings observed by Nomarski optics (Fig. $2 C)$. Lateral views of these structures in confocal z-sections (Fig. 3C) and confocal three-dimensional reconstructions (data not shown) show that $\mathrm{Cx} 35$ labeling corresponds to areas of contact between club endings and the lateral dendrite. Labeling with identical characteristics (Fig. 3D) was also observed using an anti-Cx35 monoclonal antibody (Chemicon MAB3045; $n=3$ ).

Club endings are not the only mixed synaptic contacts that terminate on Mauthner cells. Immunofluorescence labeling with anti-Cx35 and anti-Cx36 antibodies was also observed in other areas of Mauthner cells, including the soma (Fig. $4 A$ ), proximal portion of the lateral dendrite (Fig. $4 B$ ), and the ventral dendrite (data not shown). The intense labeling observed at the proximal portion of the lateral dendrite suggests that other octavolateralis synaptic contacts contain gap junctions composed of $\mathrm{Cx} 35$, possibly including anterior eighth nerve and lateral line afferents that are known to contact the lateral dendrite more proximally (Zottoli and Van Horne, 1983; Zottoli and Faber, 1979; Zottoli and Danielson, 1989; Zottoli et al., 1995). Moreover, large punctate labeling observed at the soma is consistent with the classical observation of large eighth nerve afferents terminating on Mauthner cell somata (Bodian, 1937).

Intense punctate labeling for $\mathrm{Cx} 35$ also was found in large vestibulospinal neurons (Fig. $4 C$ ) located in the vicinity of the tip of the Mauthner cell lateral dendrite. Vestibulospinal neurons are known to receive multiple mixed synaptic inputs from eighth nerve afferents. In this instance, $>300$ puncta are visible on the surface of the vestibulospinal neuron. A similar labeling pattern was observed in other hindbrain neurons, including large reticu- lospinal neurons located in the vicinity of the Mauthner cell ventral dendrite (Fig. 4D,E). On the basis of size and separation of puncta and size of nerve terminals on vestibulospinal and reticulospinal neurons, each punctum is presumed to represent the gap junctions of a single nerve terminal.

\section{FRIL identification of Mauthner cells}

Identification of club endings using the FRIL method was facilitated by combining electrophysiological and anatomical techniques. Physiologically identified Mauthner cells were injected with Lucifer yellow, the fish were perfusion fixed, and the brains were sectioned for FRIL. Tissue containing the distal lateral dendrite of the Mauthner cells was identified by fluorescence microscopy, frozen, fractured and replicated, and immunogold labeled by the FRIL technique. Before SDS washing and immunogold labeling, a photo map revealing the position of the dendrite relative to the grid openings was obtained by confocal microscopy (Fig. $5 A$ ). This procedure allowed us to locate the Mauthner cell lateral dendrite and to identify club endings in the replica.

By FRIL, Mauthner cells, club endings, other uninjected neurons, dendrites, nerve terminals, astrocytes, oligodendrocytes, and vascular endothelial cells were identified on the basis of es- 

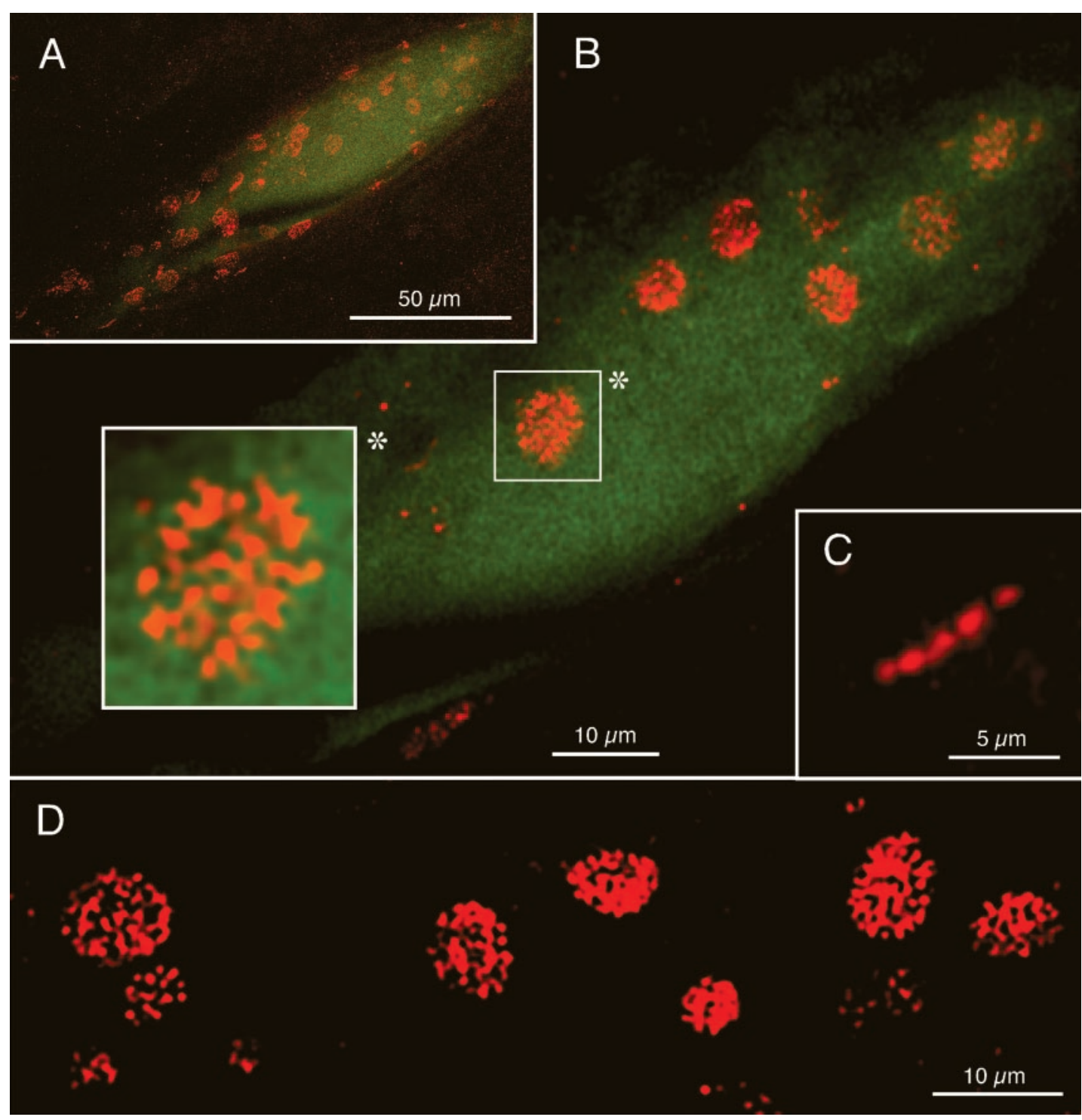

Figure 3. Laser scanning confocal immunofluorescence showing ( $\times 35$ at large myelinated club endings with polyclonal anti-Cx36 antibody Ab298. A, Confocal projection ( 30 sections; $20 \mu \mathrm{m}$ ) of the distal portion of the Mauthner cell lateral dendrite, which was physiologically identified and intracellularly injected with Neurobiotin for cell identification during confocal microscopy. Cx35 was visualized by Texas Red secondary antibody (red), and Neurobiotin was visualized by streptavidin FITC (green). B, Stack of threez-sections ( $2 \mu \mathrm{m}$ ) through the surface of the Mauthner cell lateral dendrite. Several club endings, identified by their large size and delineated by red immunofluorescence, exhibit multiple sites of punctate or patchy labeling for $\mathrm{Cx} 35$ (magnified in inset, asterisk). C, Lateral view of club ending showing restriction of labeling at lateral dendrite- club ending interface. D, Laser scanning confocal immunofluorescence showing $\mathrm{X} \times 35$ at large myelinated club endings using monoclonal anti-Cx35 antibody. Images derived from three confocal z-sections $(2 \mu \mathrm{m})$ through the surface of the distal portion of a Mauthner cell lateral dendrite show multiple labeled club endings.

tablished freeze-fracture criteria (Harris and Landis, 1986; Tuttle et al., 1986; Rash et al., 1997). At mixed synapses, presynaptic terminals were identified by the simultaneous presence of a minimum of 25 uniform-diameter synaptic vesicles in the nerve terminal cytoplasm (Fig. 5B, top left), by "active zones" and their associated membrane deformations representing ongoing exocytosis-endocytosis (Fig. 5C, white arrows), and by distinctive "rosettes" of E-face intramembrane particles (IMPs) in the presynaptic plasma membrane (Fig. 5C, black arrow). Postsynaptically, mixed synapses were identified by the presence of postsynaptic densities (PSDs), the most distinctive of which were clusters of 20-200 IMPs (10 nm diameter) in the extraplasmic leaflet (Eface) (Fig. 6), dispersed primarily at the periphery of the club ending synapses (Fig. 7), but occasionally intermixed among gap junctions. In these identified club endings, gap junctions were abundant at areas of contact with Mauthner cells (Fig. $5 B, C$, delineated in red), and almost all junctions were labeled for Cx35 with Ab298 (Fig. 5C) (10 nm gold beads).

A total of 85 gap junctions (Fig. $5 B$, delineated in red) were identified in one contiguous portion of the E-face of one of the many club endings, and an additional 20 gap junctions were clustered in the postsynaptic membrane underlying the same club ending (Fig. 5B, delineated in blue at bottom left corner). The combined value of $100+$ gap junctions is in the middle range of the number of junctional plaques within individual club endings (Tuttle et al., 1986). Of the 85 gap junctions on the club ending presynaptic membrane, 83 were labeled, and 2 small gap junctions were unlabeled (data not shown). Nineteen of the labeled gap junctions are shown at higher magnification (Fig. $5 C$ ), revealing that almost all of the immunogold beads were within junctional margins. A few beads seen outside the plaques were within $50 \mathrm{~nm}$ of the margins, as is commonly observed in FRIL replicas 
after SDS solubilization (Rash and Yasumura, 1999). Gold beads were present at a density of $\sim 300 / \mu \mathrm{m}^{2}$ in gap junctions but were rare $\left(<0.3 / \mu \mathrm{m}^{2}\right)$ beneath replicated nonjunctional plasma membranes, nuclear and cytoplasmic membranes, nucleoplasm, and extracellular space. Thus, for this sample of Mauthner cell gap junctions, the calculated "signal-to-noise ratio" (SNR) was >300:1 [SNR defined in Rash and Yasumura (1999)], and the "labeling efficiency" (defined as the number of gold beads vs the number of connexons) was $1: 36$. Both values are comparable with those in previous FRIL studies of connexins in various cell types (Fujimoto, 1995; Rash and Yasumura, 1999; Severs, 1999; Rash et al., 2001). Nevertheless, in this sample, $>95 \%$ of $>150$ gap junctions were labeled, and $100 \%$ of those consisting of $>100$ connexons were labeled. Even the smallest gap junctions often were labeled with one to five immunogold beads (Fig. $5 C$, blue arrow), thereby providing the impetus to search for gap junctions in non-Mauthner cell neurons (see below).

In FRIL, as in conventional freezefracture replicas (Rash et al., 2001; Nagy et al., 2003), the fracture plane within gap junctions always separates connexons at their site of contact in the extracellular space (Fig. 6A). Regardless of whether the gap junction is visualized as arrays of pits in the E-face of the upper cell or as IMPs in the protoplasmic leaflet (P-face) of the lower cell, or as a combination of E-face pits and $\mathrm{P}$-face particles (cases in which the fracture plane skips from the lower cell to the upper cell membrane within a junctional plaque), all connexons of the upper cell are removed during the fracturing event, leaving all connexons of the lower cell available for potential immunogold labeling (Fig. 6B, C). The retention of connexons from only one cell in each freezefractured gap junction, in combination with examination of labeled gap junctions on both sides of the same Mauthner cell, allowed identification of connexins in both presynaptic and postsynaptic plasma membranes (Fig. 6C). In contrast to this immunolabeling pattern of gap junctions beneath both E-face pits and P-face particles (Fig. 6C, bottom left), freeze-fractured PSDs are labeled only beneath their replicated IMPs (Figs. 6C, lower right, 7, 9). Depending on the type(s) of receptor(s) within a PSD, these IMPs may segregate to either E- or P-faces during freeze-fracture; however, in the case of glutamate receptors thought to be represented by distinctive clusters of E-face IMPs (Harris and Landis, 1986), FRIL labeling is shown diagrammatically to occur only beneath the appropriate clusters of E-face IMPs, presumably on extracellular determinants re-
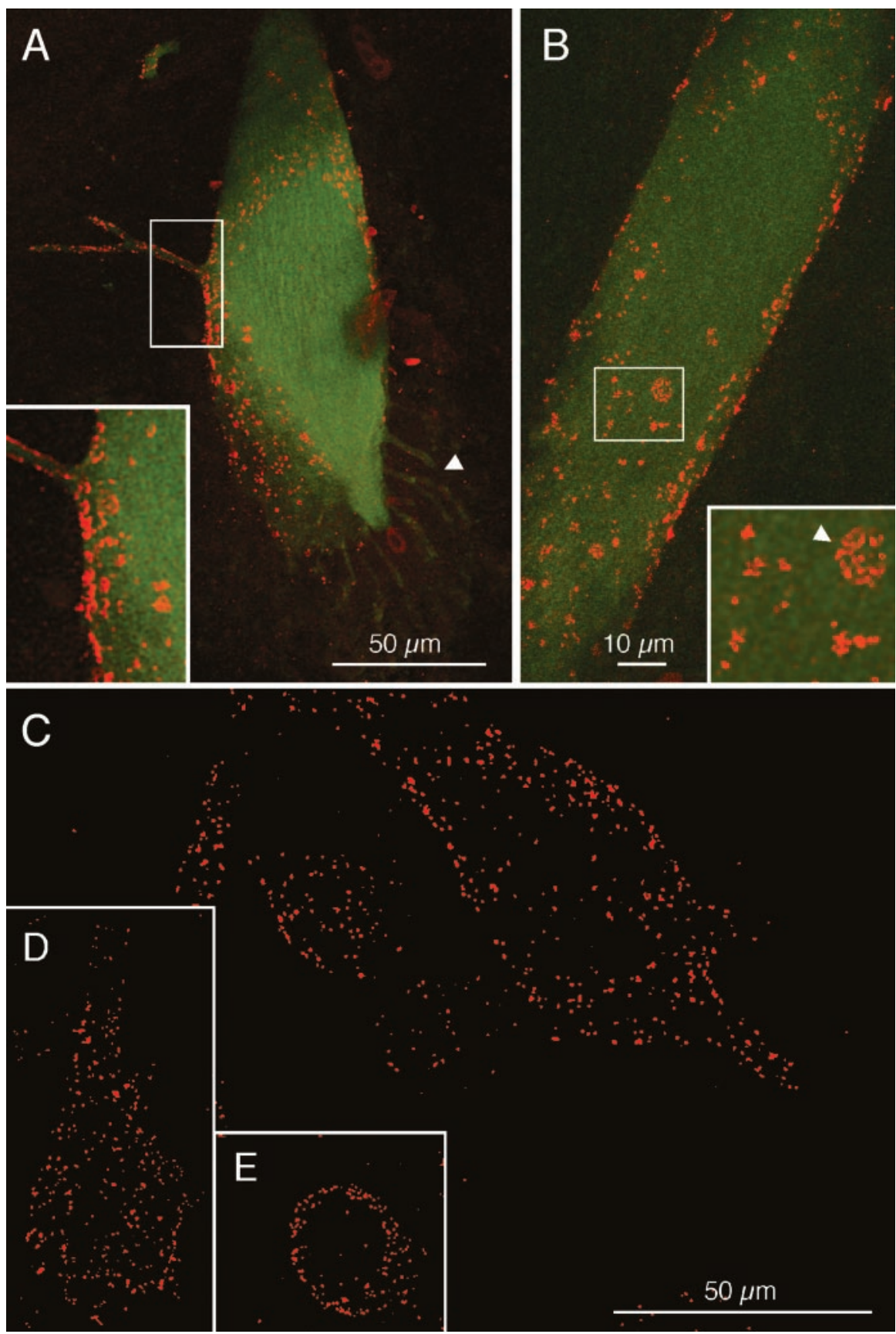

Figure 4. Laser scanning confocal immunofluorescence of $\mathrm{C} x 35$ associated with Mauthner cell somata and proximal dendrite. $A$, View of the Mauthner cell soma showing intense labeling for $\mathrm{Cx} 35$ with polyclonal Ab298 (red). The Mauthner cell was injected with Neurobiotin (green) as in Figure 3. Labeling is seen on both soma and small somatic dendritic processes (inset). Small "cap dendrites" projecting inside the axon cap (arrowhead) are also faintly labeled with Neurobiotin. B, View of a most proximal region of the lateral dendrite where a club ending in the boxed area (magnified in inset, arrowhead) appears among other terminals of smaller size, likely corresponding to anterior eighth nerve or lateral line inputs to the Mauthner cell, or both. $C-E$, Labeling of $C \times 35$ (Ab298) associated with neurons in various regions of goldfish hindbrain. Image shows a confocal projection of large vestibulospinal $(C$ and two reticulospinal $(D, E)$ neurons. Punctate labeling is seen dispersed throughout the surface of these neurons.

maining within the SDS-washed synaptic cleft (Fig. 6C, right side).

\section{Cx35 is present presynpatically and postsynaptically at large} myelinated club endings

To establish ultrastructurally that $\mathrm{Cx} 35$ is localized to gap junctions, and to determine whether the same connexin is present on both the club ending and Mauthner cell sides of gap junction 

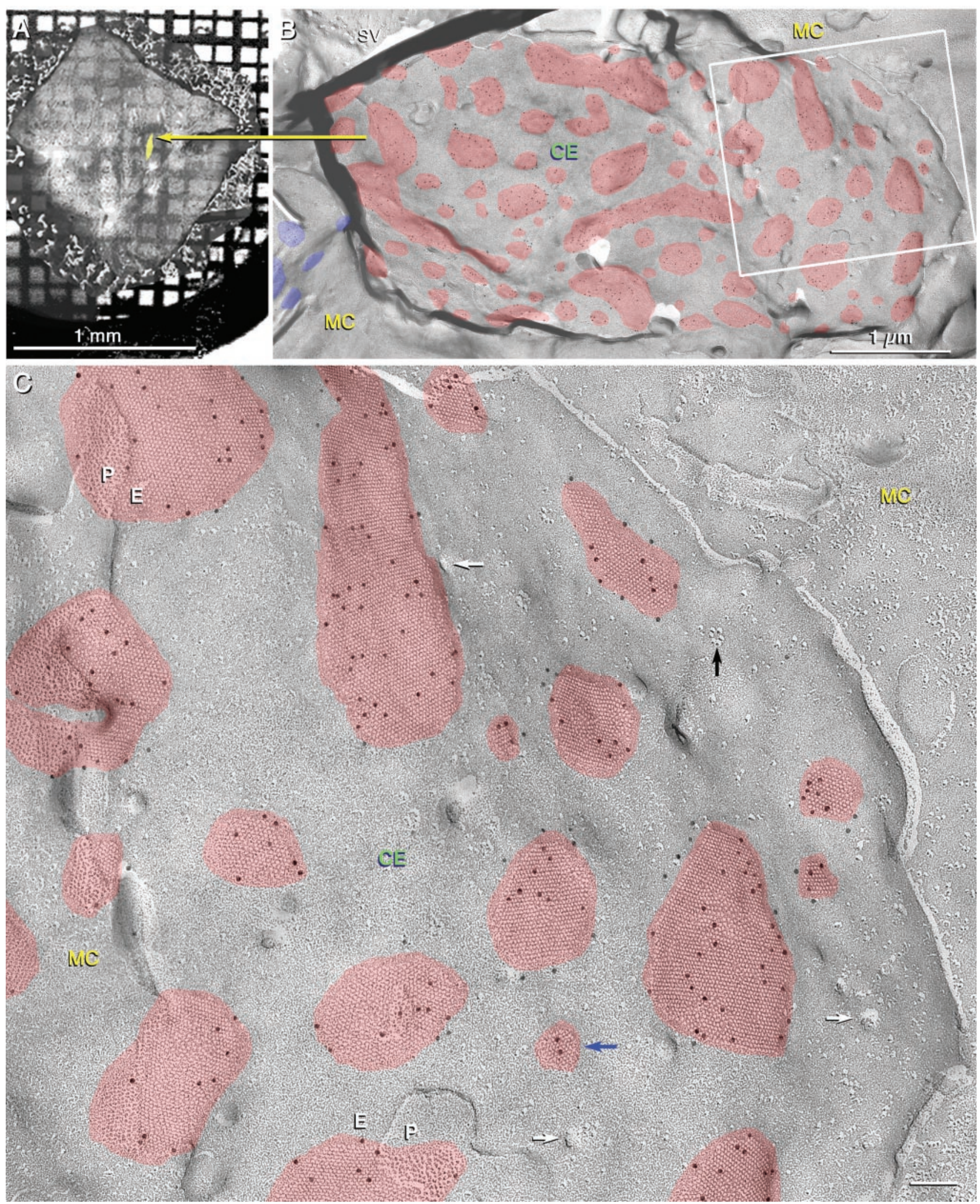

Figure 5. FRIL images of $C \times 35$ localization at gap junctions between a Mauthner cell lateral dendrite and large myelinated club endings. $A$, Confocal micrograph of a FRIL replica containing a Lucifer yellow-injected Mauthner cell bonded to a gold index grid. Fracture plane traverses obliquely through the Mauthner cell, revealing views from club ending toward Mauthner cell ( $B, C$ and from Mauthner cell toward club ending (Fig. 7). Yellow arrow indicates approximate location of club ending illustrated in $B$ and C. At this light microscopic magnification, the yellow arrowhead covers $\sim 2000 \mu \mathrm{m}^{2}$ of the sample, whereas the endplate in Figure $5 B$ covers $\sim 12 \mu \mathrm{m}^{2}$. B, FRIL image showing one club ending with 85 gap junctions (red areas), 83 of which are immunogold labeled for $C \times 35$. CE, Club ending; $M C$, Mauthner cell; SV, synapticvesicles; blue areas, labeled Mauthner cell gap junctions at adjacent club ending. The area shown is equivalent to $2 \%$ of the area of a single grid opening in Figure $7 A$, or less than one pixel of the image. C, Higher magnification of boxed area in B showing E-face view of club ending (CE) surrounded by P-face of Mauthner cell plasma membrane (MC). In this area, 19 of 19 gap junctions are labeled with $10 \mathrm{~nm}$ gold beads. Blue arrow, Gap junction with $\sim 30$ connexons labeled by two immunogold beads. White arrows, Exocytotic vesicle remnants in the club ending plasma membrane; black arrow, rosette of E-face IMPs typically seen in nerve terminal plasma membranes. Scale bars (in FRIL images): $0.1 \mu$ m unless designated otherwise. 

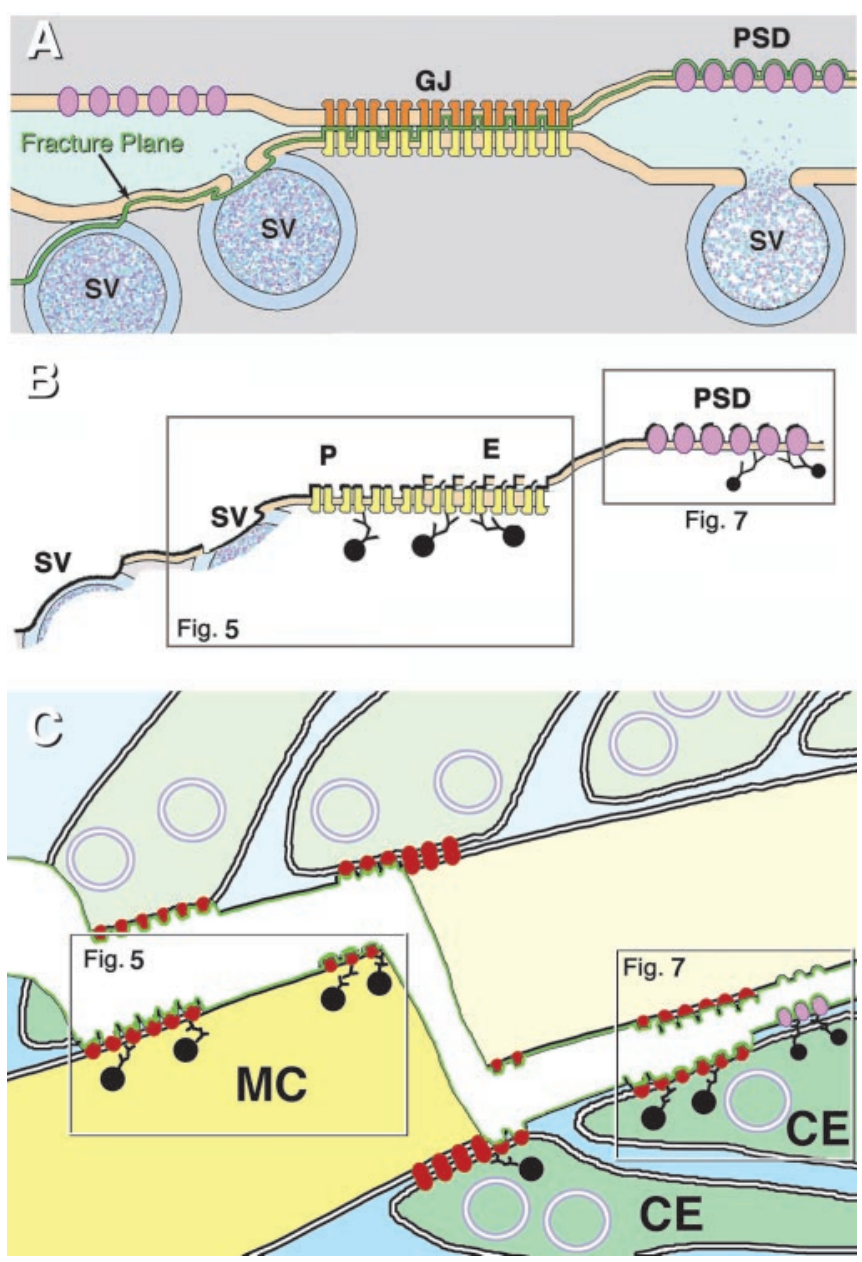

Figure 6. Basis for FRIL identification of membrane proteins. $A, B$, Diagram showing portions of a mixed synapse before $(A)$ and after freeze fracturing and immunogold labeling $(B)$. The fracture plane ( $A$, green line) separates connexons at the point of contact in the extracellular space, leaving either intramembrane particles (IMPs) in the $P$-face (P) or arrays of pits in the E-face (E). All gap junctions exposed by fracturing are separated into two hemiplaques; one hemiplaque remains associated with each of the two freeze-fractured cells. Whether E-face pits or P-face particles are visualized by FRIL, antibody labeling of connexins and secondary immunogold beads bind only to connexins in the hemiplaque of the cell with a cytoplasmic membrane leaflet that remains beneath the replica. ForE-face images, all connexons of the upper cell are removed, but connexons remain within the unsplit membrane of the underlying, nonvisualized cell. For intramembrane proteins other than connexins, however, immunogold labeling sites are present only beneath replicated IMPs, on either E-faces or P-faces. Proteins comprising PSDs of glutamatergic synapses consist of distinctive clusters of E-face IMPs $(B)$, which are available for immunogold labeling of determinants exposed in the residual extracellular space. C, Diagram of fracture plane through an individual Mauthner cell, including views from the presynaptic side toward the postsynaptic side (top left) and from the postsynaptic side toward the presynaptic side (bottom right). Glutamate receptor PSDs are clusters of E-face IMPs that are immunogold labeled on their extracellular determinants.

plaques, we used FRIL to examine both sides of individual obliquely fractured Mauthner cells that have been labeled using Ab298. The fracture plane in the replica illustrated in Figures 5 and 7 passed obliquely through one Mauthner cell lateral dendrite, thus exposing both presynaptic and postsynaptic views of two different club endings located on opposite sides of the same lateral dendrite (represented diagrammatically in Fig. $6 C$ and illustrated in Figs. $5 B, C$, and Fig. $7 A$ ). Thus, the two FRIL views of synapses on the same Mauthner cell reveal that Cx35 labeling occurred on connexons within the postsynaptic plasma membranes (Fig. $5 B, C$ ), as well as within the presynaptic plasma membrane (Fig. 7; represented diagrammatically in Fig. 6A, B), thereby demonstrating that both sides of the gap junctions formed between Mauthner cell lateral dendrites and club endings contain Cx35.

\section{Postsynaptic densities at large myelinated club endings contain NMDA receptors}

Pharmacological and immunochemical data suggest that chemical transmission at club endings is mediated by glutamate (Sur et al., 1994; Wolszon et al., 1997). In postsynaptic views of club ending mixed synapses (shown diagrammatically in Fig. 6), distinctive PSDs containing 30-200 E-face IMPs were observed at the margins of the synaptic contacts, and in those areas, PSDs were adjacent to gap junction plaques (Fig. 7A, yellow areas). These PSDs appeared similar to presumptive glutamate receptor PSDs in conventional freeze-fracture replicas of adult mammalian hippocampus (Harris and Landis, 1986). In the same sample of goldfish brain, the replica was double labeled for $\mathrm{Cx} 35$ with 10 nm gold beads (Fig. $5 B, C$ ), as well as for glutamate receptor NR1 subunits using 6 and $18 \mathrm{~nm}$ gold beads (Figs $7 B-D$; illustrated diagrammatically in Fig. $6 B, C$ ). Double labeling revealed the presence of $\mathrm{Cx} 35$ in gap junctions and NR1 glutamate receptors in nearby E-face PSDs in identified Mauthner cells (Fig. 7C-E, yellow areas), including at identified club ending synapses (Fig. $7 D$ ) and in other synapses that because of their size, location, and complement of abundant gap junctions likely correspond to Mauthner cell club ending synapses (Fig. 7C). Although the area occupied by each PSD was similar to those of gap junctions, the number of IMPs and the number of labels per PSD were only $\sim 20 \%$ of that in gap junctions, thereby yielding labeling efficiencies of $\sim 1: 30$ for both gap junctions and for this distinctive class of PSDs. Furthermore, a small number of immunogold labels is expected because NMDA receptors constitute only a small fraction of the glutamate receptors present at PSDs (Takumi et al., 1999). On the basis of the criteria described above, we found nine labeled PSDs in Mauthner cell mixed synapses, and an additional five NR1-labeled PSDs in nearby unidentified neurons (see below).

To confirm that NR1 is present at club endings, we performed experiments using a previously characterized teleost anti-NR1 antibody $(n=3)$, directed against the NR1 subunit of the electric fish Apteronotus (Berman et al., 2001), that, in contrast with the anti-NR1 use for FRIL, yielded distinct labeling on the Mauthner cell lateral dendrite. As in the case of Cx35 labeling (Fig. 3), confocal microscopy revealed large immunofluorescent ovoid areas at the distal portion of the lateral dendrite that, given their size and subcellular location, presumably correspond to club endings (Fig. 7E). In contrast with the Cx35 labeling, and consistent with ultrastructural data describing the predominance of PSDs in the periphery of these terminals (Tuttle et al., 1986), the labeling was localized primarily to the periphery of these ovals, where the contact area of each club ending was delineated by multiple NR1 fluorescent patches.

\section{FRIL confirms that connexin 35 and NR1 are widespread among neurons}

Immunogold labeling for $\mathrm{Cx} 35$ was not restricted to club endings but was also found in other mixed synapses located in the proximity of Mauthner cells. In a sample of goldfish brain examined for Cx35 with MAB3045 (monoclonal anti-perch Cx35), neuronal gap junctions were labeled with 6,18 , and $20 \mathrm{~nm}$ gold beads (Fig. 8). The presence of three sizes of immunogold beads provides three different confirmations of labeling specificity of this 

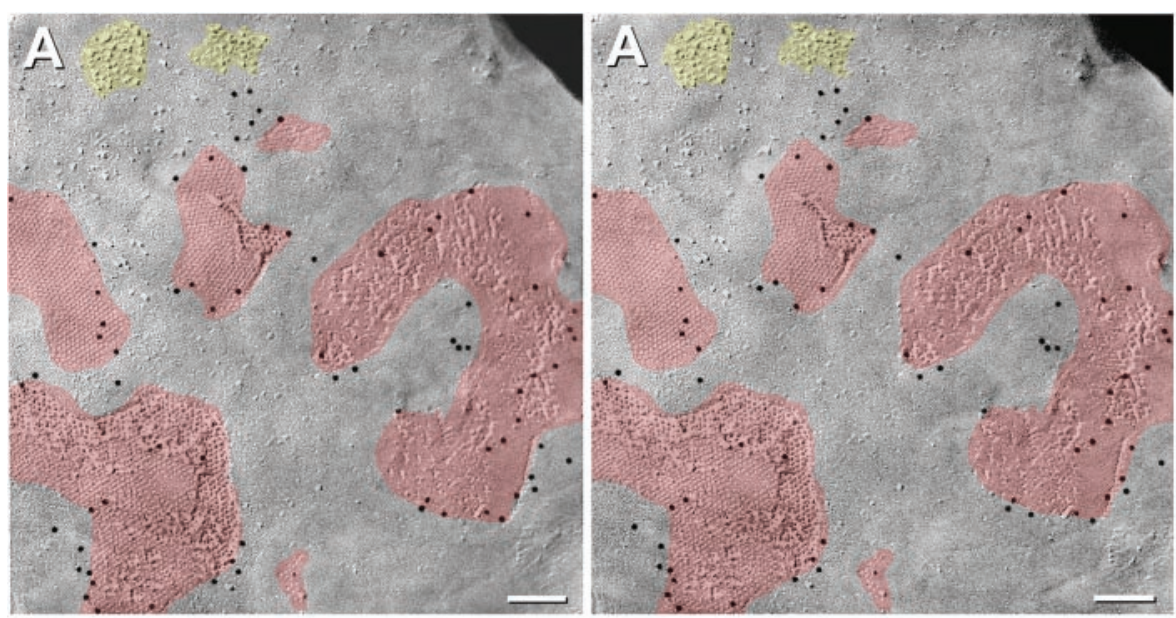

\section{E}
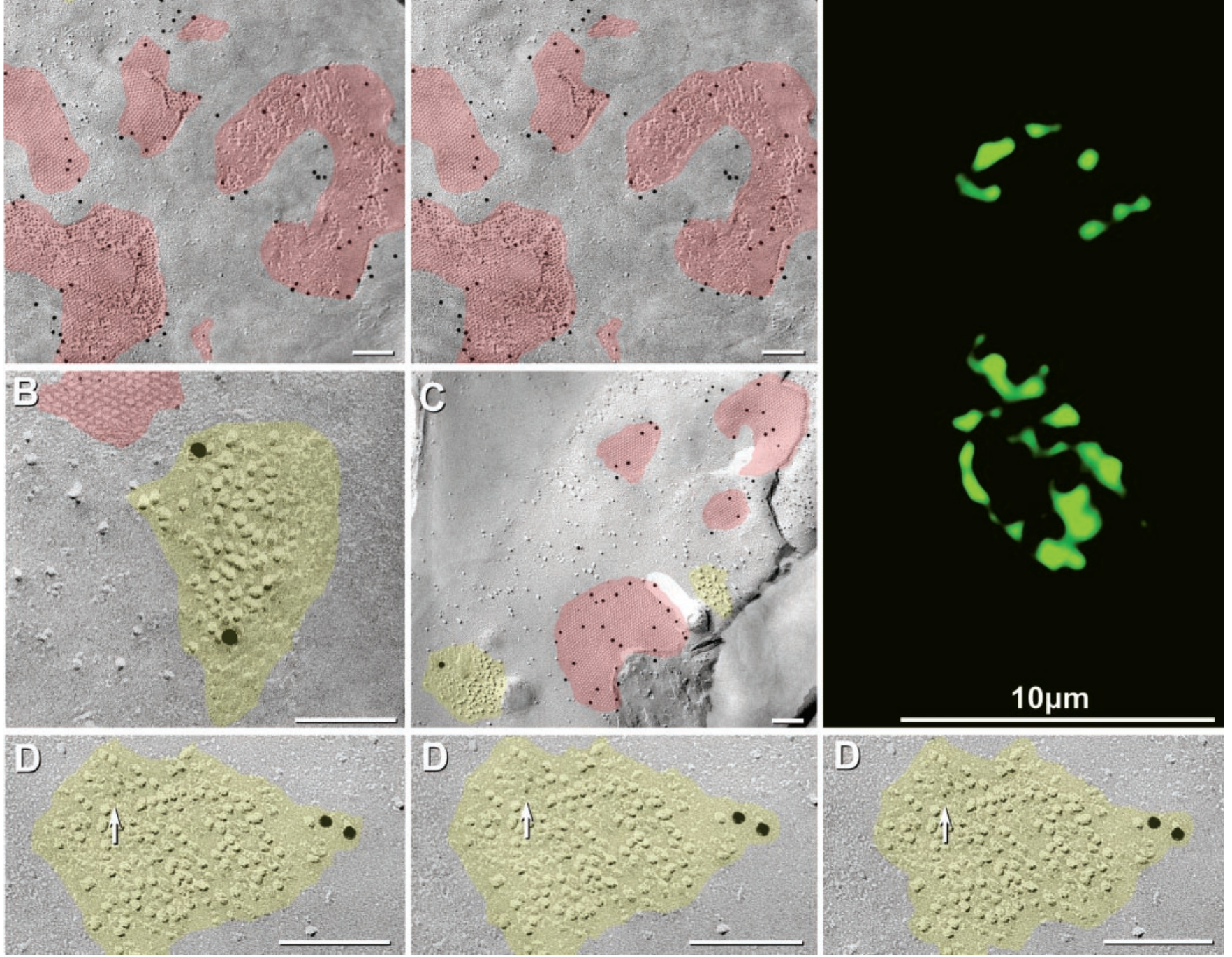

Figure 7. FRIL double labeling of $(x 35$ in gap junction plaques within the presynaptic membrane and of NR1 subunit of NMDA glutamate receptors in nearby IMPs in postsynaptic particle clusters (designated PSDs) in the postsynaptic membrane. A, Gap junctions and PSDs in postsynaptic membrane of a Mauthner cell. (x35 labeling (Ab298) is approximately as dense in the presynaptic membrane as in postsynaptic membranes elsewhere in the same cell (Fig. 5C). B, Simultaneous double labeling for $(x 35$ ( $6 \mathrm{~nm}$ gold beads) and for glutamate receptor NR1 (18 nm gold beads) in a PSD of an identified Mauthner cell club ending in a different replica. The PSD (yellow) contains $10 \mathrm{~nm}$ IMPs, some of which were damaged by scraping during the fracturing event (right side of PSD). C, Four of five (x35-labeled gap junctions ( $10 \mathrm{~nm}$ gold beads) in a small portion of a club ending on the same Mauthner cell as shown in Figures 5 and 7 A. A nearby small PSD is labeled for NR1 (18 $\mathrm{nm}$ gold bead). Because membrane continuity was interrupted, identification as a club ending was on the basis of synapse size, number of closely spaced gap junctions, and FRIL mapping criteria. $D$, NR1-labeled PSD in a non-club ending synapse in the same Mauthner cell illustrated in Figures 5 and 7 . As above, CX35 is labeled by $10 \mathrm{~nm}$ gold (none present here), whereas NR1 is labeled by $6 \mathrm{~nm}$ (arrow) and $18 \mathrm{~nm}$ gold beads. The PSD is shown in stereoscopic (left pair) and reverse stereoscopic perspective (right pair). In reverse stereoscopic perspective, the smallest gold beads ( $6 \mathrm{~nm}$ ) are readily discerned as if suspended above the replicated 6-10 nm IMPs. E, Laser scanning immunofluorescence showing NR1 at large myelinated club endings with anti-AptNR1 antibody. The image represents a stack of three z-sections $(2 \mu \mathrm{m})$ through the surface of the $\mathrm{M}$-cell lateral dendrite. Two club endings, identified by their large size and location, are delineated by green immunofluorescence. Each exhibits multiple punctate labeling that, in contrast with Cx35 (Fig. 3), is restricted to the perimeter of the contacts.

monoclonal antibody. Immunogold beads were found restricted to neuronal gap junctions (Fig. $8 B$ ).

Although neuronal gap junctions were heavily labeled by the several antibodies to Cx35, no gap junctions between any other non-neuronal cell types were labeled for Cx35. For example, closely adjacent astrocyte gap junctions were unlabeled (Fig. $8 A, C$ ). In a higher magnification stereoscopic image of one of the immunogold-labeled neuronal gap junctions (Fig. $8 B$, left pair), and in its intaglio image (Fig. $8 B$, right pair), 19 $6 \mathrm{~nm}$ gold beads (arrow), $318 \mathrm{~nm}$ gold beads, and $320 \mathrm{~nm}$ gold beads are seen, all representing labeling for Cx35. This image also demonstrates higher labeling efficiencies for small gold beads and lower labeling efficiency for large immunogold beads (Rash et al., 2001). Although small gold beads were more efficient as labels, their small size made them more difficult to detect and, moreover, required stereoscopic imaging for unambiguous discrimination from IMPs having a similar size and electron density. Overall, the combined labeling efficiency for the three sizes of immunogold beads in this particular gap junction was $\sim 1: 12$, an unusually high ratio for FRIL, presumable reflecting the higher labeling efficiency for $6 \mathrm{~nm}$ gold beads. Finally, the presence of three sizes of gold beads restricted solely to neuronal gap junctions and not to nearby astrocyte gap junctions (Fig. 8C) provided three independent 

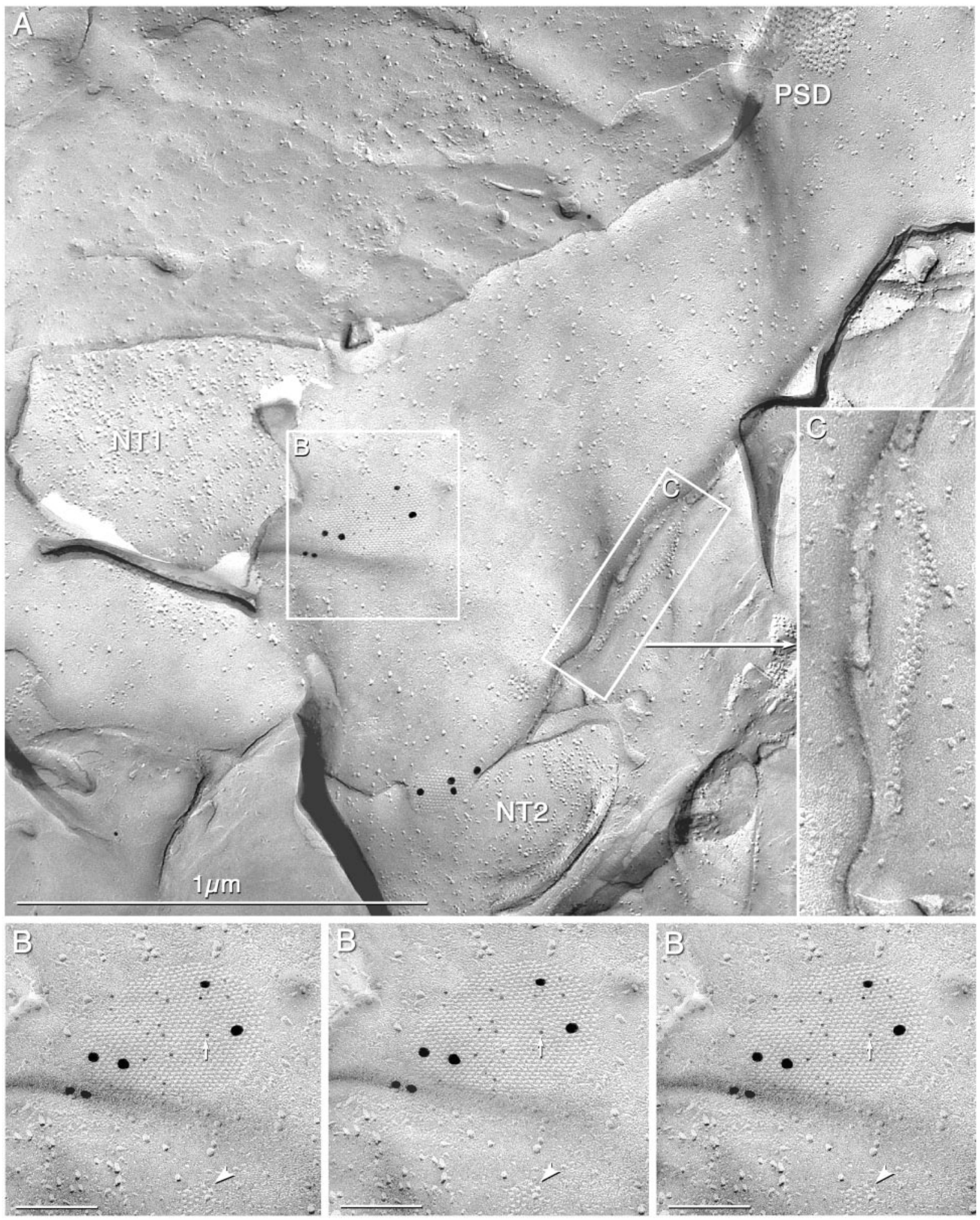

Figure 8. FRIL labeling of $\mathrm{Cx} 35$ in gap junctions at mixed synapses of unidentified neurons in goldfish hindbrain. $A$, Freeze-fracture view of the postsynaptic $\mathrm{E}$-face and of two nerve terminal P-faces (NT1, NT2). Gap junctions are labeled with three sizes of gold beads. B, Higher magnification view of left boxed area in $A$, shown as stereoscopic images (left pair) and reverse stereoscopic images (right pair). Cx35 is labeled with $196 \mathrm{~nm}$ gold beads (arrow), $318 \mathrm{~nm}$ gold beads, and $320 \mathrm{~nm}$ gold beads. The field also contains a small unlabeled gap junction (arrowhead). C, Area of Mauthner cell with closely adherent astrocyte processes. Astrocyte gap junctions were not labeled for CX35.

verifications of neuronal labeling specificity for the teleost antibody, made against perch Cx35.

A third anti-Cx36 antibody (Zymed Ab-6300) also was found to be effective for identifying goldfish neuronal gap junctions by
FRIL. In two mixed synapses on an unidentified neuronal process in close proximity to a mapped Mauthner cell, one gap junction was labeled by five $20 \mathrm{~nm}$ immunogold beads (Fig. 9A, large inset), and one nearby small gap junction was unlabeled (small 

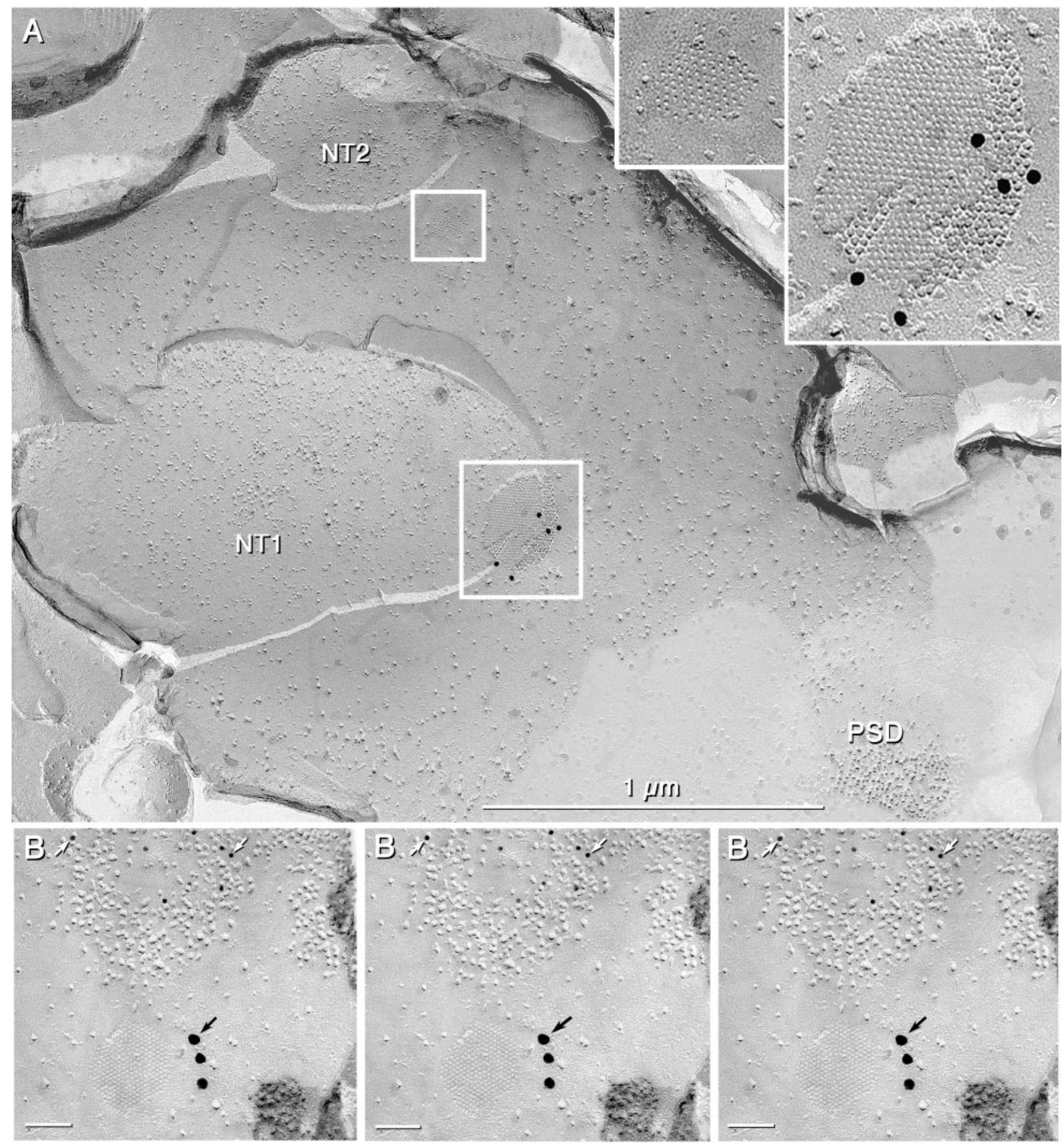

Figure 9. FRIL single labeling for $C \times 35(A)$ and double labeling for $C \times 35$ and NR1 $(B)$ in mixed synapses between unidentified neurons in goldfish hindbrain. $A$, Two gap junctions (inscribed areas, magnified in inset at top right) linking nerve terminals (NT1, NT2) to postsynaptic membrane. One gap junction is unlabeled (top inset), and the other (bottom inset) is labeled by five $20 \mathrm{~nm}$ gold beads. Also evident is a PSD at the bottom right. B, Double-labeled mixed synapse with NR1 in the PSD labeled by $10 \mathrm{~nm}$ gold beads (white arrows) and the gap junction labeled for (x35 by $20 \mathrm{~nm}$ gold beads (black arrow). Immunogold beads up to $50 \mathrm{~nm}$ from the margins of gap junctions presumably represent labeling of connexins in dissolving membrane blebs, as illustrated in Rash and Yasumura (1999), their Figure 9.

inset). The cluster of E-face IMPs in the bottom right corner resembles glutamate receptor-containing PSDs (Fig. 7). Consequently double labeling for NR1 and Cx35 was evaluated in other types of neurons. Double labeling for Cx35 and NR1 in hindbrain regions revealed NR1 labeling in five mixed synapses in five unidentified neurons. As in the case of Mauthner cell mixed synapses (Fig. 7), these contained Cx35 (30 nm gold) in their gap junctions and NR1 receptors (10 nm gold) in their closely associated E-face PSDs (Fig. 9B). Additional glutamate receptor PSDs were found at purely chemical synapses (data not shown).
Connexin 43 labeling is restricted to astrocytic gap junctions

Immunofluorescence localization of $\mathrm{Cx} 43$ by confocal microscopy was conducted to investigate whether $\mathrm{Cx} 43$ contributes to electrical transmission at club endings, as suggested previously (Yox et al., 1990). In goldfish brains $(n=4)$ examined with fluorescent anti-Cx43 antibodies, labeling was observed at the periphery and apparently on the surface of the Mauthner cell dendrite (Fig. 10). To determine cell-type association of Cx43, and in particular, whether $\mathrm{Cx} 43$ has any anatomical relation to club endings, immunolabeling for this connexin was conducted 
A

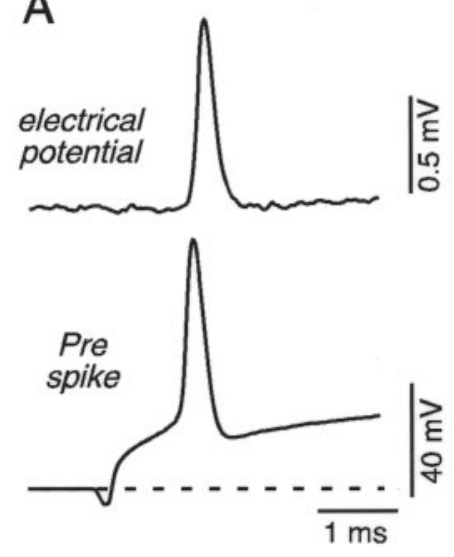

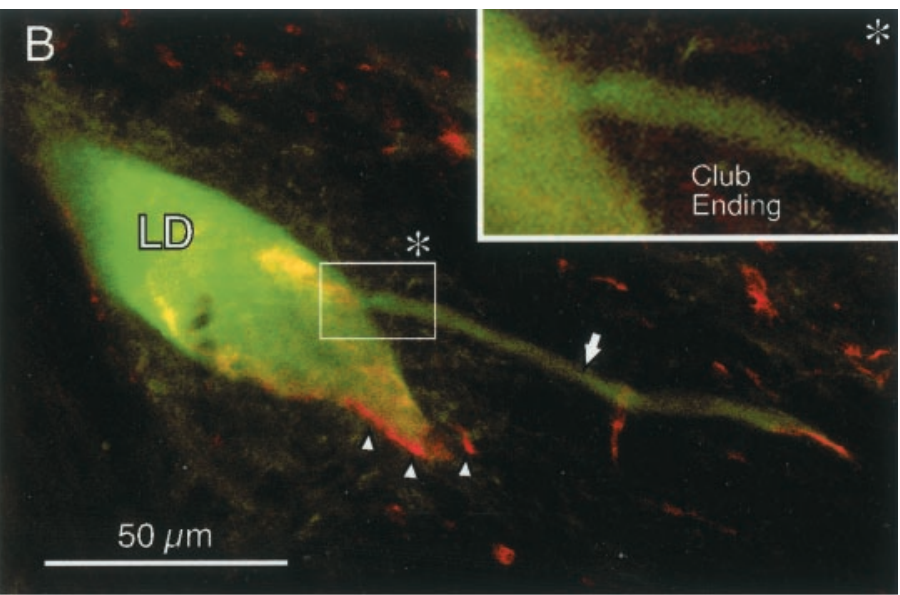
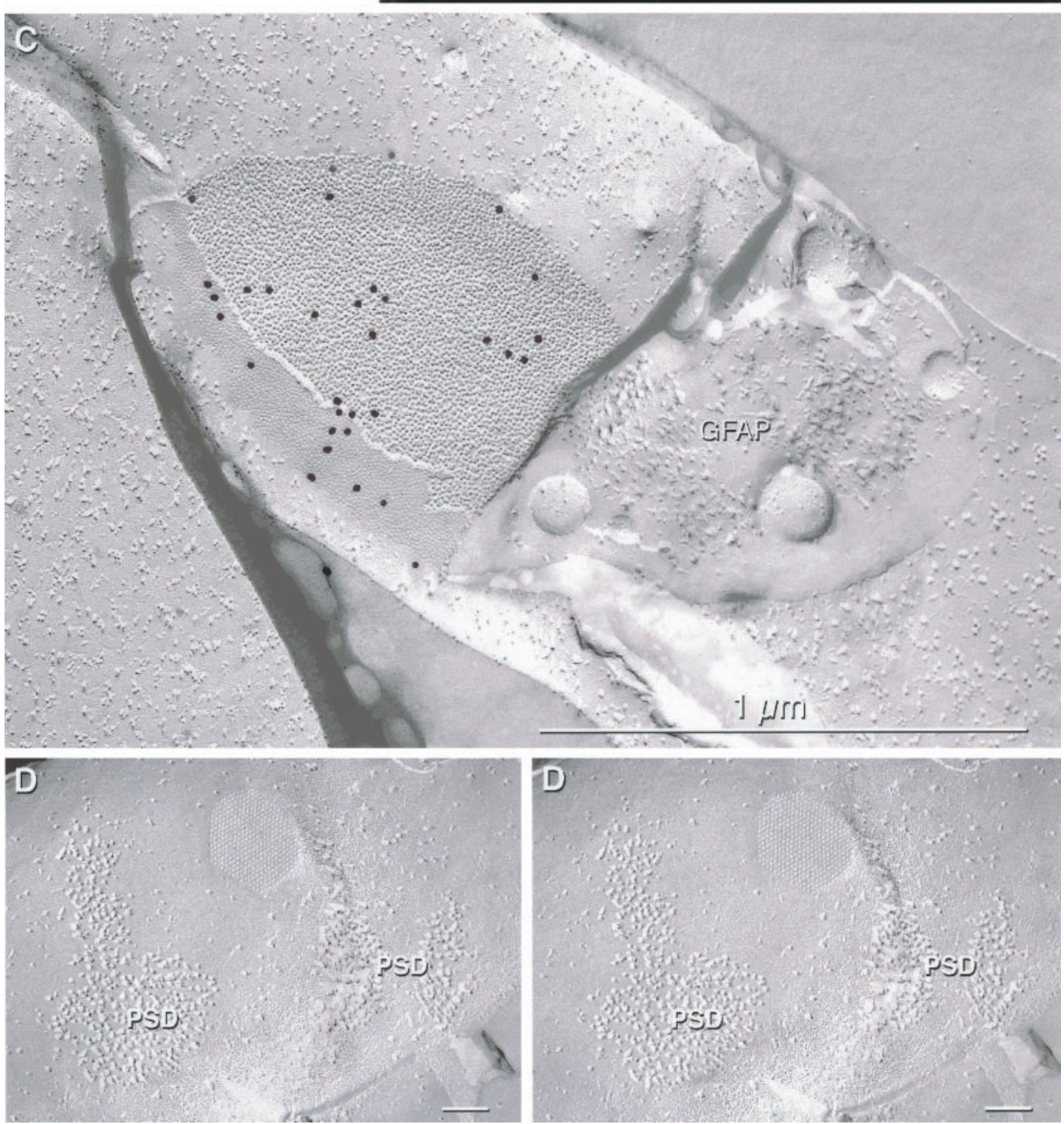

Figure 10. Localization of $\mathrm{C} x 43$ near Mauthner cell lateral dendrites. $A$, Presynaptic and postsynaptic simultaneous unitary recording $(A)$ from the labeled club ending and dendrite illustrated in $B$. The presynaptic electrode was inserted into afferent fibers of the posterior eighth nerve root and therefore differs from the recording in Figure $2 E$, where the presynaptic electrode was inserted in the presynaptic terminal, allowing detection of subthreshold responses. No chemical component was detected at this contact, a common observation at these terminals during unitary recordings (Lin and Faber, 1988). Data represent the average of 20 individual traces. B, Confocal immunofluorescence labeling for $\mathrm{X} 43$ (red) after simultaneous intracellular injection of Mauthner cells and eighth nerve fibers with Neurobiotin (green). Punctate staining for $\mathrm{Cx} 43$ (arrowheads) is seen around the periphery of the Mauthner cell lateral dendrite (LD) but not at the junction between Neurobiotin-labeled club endings (arrow) and the lateral dendrite (inset, arrow). C, FRIL labeling of (x43 at astrocyte gap junction displaying $3320 \mathrm{~nm}$ gold beads. The astrocyte process was identified as such on the basis of the presence of GFAP filaments (GFAP) in the cytoplasm and by the characteristic high density of E-face particles (bottom right). D, Gap junction located between two PSDs in the E-face of an unidentified neuron in the same replica as illustrated in C is devoid of labeling for Cx43. 
after intracellular injection of Neurobiotin into both Mauthner cells and club endings during simultaneous recordings from these cells (Fig. 10A). No labeling for Cx43 (Fig. 10 B, red fluorescence; polyclonal) was observed at junctions between physiologically identified club endings and the Mauthner cell dendrite (Fig. $10 \mathrm{~B}$, green), but $\mathrm{Cx} 43$ labeling was found in neighboring cell processes and around the dendrite, consistent with the well established presence of this connexin in astrocytes (Dermietzel et al., 1989, 1991; Dermietzel and Spray, 1993; Rash et al., 2000, 2001).

In samples of goldfish brain labeled for $\mathrm{Cx} 43$ (monoclonal) with $20 \mathrm{~nm}$ immunogold beads and examined by FRIL, >100 Cx43-containing gap junctions were detected. All of the labeled gap junctions were within astrocyte plasma membrane (Fig. $10 C)$. Astrocytes were identified by the presence of GFAP filaments in their cytoplasms (Fig. 10C) and by a characteristic high density of dispersed IMPs in their E-faces (Rash et al., 1997). Unlike mammalian astrocyte plasma membranes, which contain aquaporin-4 (AQP4) square arrays that allow routine identification of these cells in freeze-fracture replicas (Rash et al., 1998, 1999), AQP4 square arrays are not present in goldfish astrocyte plasma membranes (Wolburg et al., 1983), thus precluding their use as markers to identify astrocytes.

In the same Cx43-labeled FRIL replica, neuronal gap junctions were found at mixed synapses, but none were labeled for Cx43 (Fig. 10 D). This close juxtaposition of Cx43-labeled astrocyte gap junctions and unlabeled neuronal gap junctions is compelling evidence that $\mathrm{Cx} 43$ is not present in detectable amounts in neuronal gap junctions in goldfish hindbrain.

\section{Discussion}

Gap junctions at large myelinated club endings contain Cx35 Studies of large myelinated club endings led to early insights into the mechanisms of electrical transmission between neurons (Bennett at al., 1963; Furshpan, 1964) and to the first hints of the complex structure of gap junctions (Robertson et al., 1963; for review, see Bennett, 1977). Subsequently, it was shown that club endings are linked to Mauthner cell lateral dendrites by 63-200 closely spaced gap junctions and that each terminal contains a total of 24,000-106,000 connexons (Nakajima, 1974; Tuttle et al., 1986). Moreover, Tuttle and coworkers (1986) showed that surrounding the gap junctions were distinctive PSDs composed of 10 nm E-face IMPs. We now extend those studies by identifying $\mathrm{Cx} 35$, the fish ortholog of human and mouse Cx36, as a major connexin in electrical synapses formed by club endings, and glutamate receptors in the associated PSDs.

Confocal immunofluorescence microscopy revealed abundant Cx35 in Mauthner cell/club ending synapses. These synapses were identified by their uniquely large size and distinctive subcellular location on lateral dendrites, as well by confocal gridmapping of Mauthner cell lateral dendrites that had been injected with Lucifer yellow during intracellular recordings. Immunofluorescence mapping followed by FRIL revealed abundant Cx35 in gap junction plaques at these club ending synapses. Thus, the ability to combine physiological and ultrastructural analysis at club endings on Mauthner cells provides a powerful system to explore detailed mechanisms of electrical transmission in the vertebrate brain.

The intensity of labeling for Cx35 observed by confocal microscopy and the presence of this connexin in virtually every gap junction plaque as demonstrated by FRIL indicates that Cx35 is a major component of these junctions and thus primarily responsible for electrical transmission at club endings. Moreover, our identification of $\mathrm{Cx} 35$ on both the Mauthner cell and club ending side of gap junctions between these structures suggests that electrical transmission at club ending synapses may occur through homotypic gap junction channels. Interestingly, and in contrast with FRIL labeling with Ab298 antibody, we did not observe postsynaptic labeling of gap junctions in club endings with the monoclonal Cx35 antibody (MAB3045). This may reflect the limited number of views seen using this antibody, differences in labeling efficiency of epitopes exposed in presynaptic versus postsynaptic cytoplasm, or differences between presynaptic and postsynaptic connexins. Nevertheless, we do not exclude that additional connexins may be present at club ending gap junction plaques and that these may be expressed differentially.

By combining quantitative analysis of the average number of connexons in individual club endings (Tuttle et al., 1986) with estimates of junctional resistance at single terminals (Lin and Faber, 1988), previous reports suggested that a very small fraction ( $\sim 2 \%$ ) of the morphologically observed channels at these contacts were open at a given time (Tuttle et al., 1986; Lin and Faber, 1988). A unitary channel conductance of $100 \mathrm{pS}$ was assumed in those estimates; however, the unitary conductance of Cx35 (M. Srinivas and T. White, personal communication) and Cx36 channels (Srinivas et al., 1999; Teubner et al., 2000) is now known to be on the order of only $10-15 \mathrm{pS}$. Thus, a recalculation on the basis of our finding of $\mathrm{Cx} 35$ in club ending junctions would suggest that as many as $15-20 \%$ of the total number of channels may be open at a given time. This new estimate for number of open channels, although at least seven times larger than previous estimates, nevertheless represents only a small fraction of the total number of connexons. Moreover, both estimates are consistent with another study in which the ability of cells to express Cx43 fused with enhanced green fluorescent protein was used to examine the relationship between clustering of gap junctions channels and electrical coupling, revealing that only a small fraction of channels were functional (Bukauskas et al., 2000).

Anti-Cx43 antibodies injected into Mauthner cells were reported to alter electrical coupling of these cells, leading to the conclusion that $\mathrm{Cx} 43$ is responsible for electrical transmission at club endings (Yox et al., 1990). Although our immunocytochemical data confirm that punctate immunofluorescence staining for Cx43 is abundant around the distal portion of the lateral dendrites, FRIL revealed that $\mathrm{Cx} 43$ was not detectable in Mauthner cell gap junctions but was abundant in nearby astrocyte gap junctions. Moreover, three-dimensional mapping at the limit of resolution of confocal microscopy of Neurobiotin-injected afferents showed absence of $\mathrm{Cx} 43$ immunofluorescence at the area of contact between club endings and Mauthner cell lateral dendrites. Thus, Mauthner cell-associated Cx43 labeling corresponds to gap junctions between astrocytic processes that surround club endings and not to neuronal-neuronal or (hypothetical) neuronalglial gap junctions.

\section{Cx35-mediated electrical transmission is widespread in the goldfish hindbrain}

Confocal microscopy revealed that Cx35 labeling was not restricted to club endings; intense punctate staining was also observed at the proximal portion of Mauthner cell lateral dendrite, soma, and ventral dendrites. Thus, other electrical synapses on Mauthner cells, presumably arising from auditory afferents, anterior eighth nerve, and lateral line inputs, also contain Cx35. In addition, Cx35 labeling was observed in other hindbrain neurons known to receive electrically mediated inputs, including large vestibulospinal (Richter et al., 1975; Korn et al., 1977) and reticu- 
lospinal neurons (Rovainen, 1974), revealing that Cx35mediated transmission is a common feature in the goldfish brain. These findings agree with earlier reports that electrical synapses are widespread in teleost brain (Bennett, 1977). Further confirming these observations, FRIL revealed that labeling for Cx35 was present in and restricted to neuronal junctions in widespread areas of goldfish hindbrain. Moreover, such neuron-specific and glial cell-specific expression of connexins is consistent with similar cell-specific connexin expression reported for mammalian CNS (Rash et al., 2001) and supports the view that Cx35 and Cx36 mediate electrical synaptic transmission in vertebrates.

\section{Activity-dependent plasticity of electrical synapses}

Gap junctions located at club endings are dramatically influenced by cellular activity. High-frequency stimulation of these afferents evokes a long-lasting enhancement of electrical transmission. Such activity-dependent modification of the strength of electrical transmission seems to depend on functional interactions with neighboring, colocalized glutamatergic synapses. Thus, it has been proposed that NMDA receptors (Yang et al., 1990) acting postsynaptically via local calcium signaling cause activation of calcium-calmodulin-dependent kinase II, which is essential for induction of the modifications (Pereda and Faber, 1996; Pereda et al., 1998). These electrophysiological findings are supported by the present demonstration by confocal microscopy of glutamate receptor NR1-immunogold labeling at large myelinated club endings. Furthermore, the ultrastructural demonstrations of glutamate receptor NR1-immunogold labeling at PSDs adjacent to gap junctions in mixed synapses of other unidentified neurons suggests that this structural and functional association of gap junctions and glutamatergic PSDs is widespread in goldfish brain.

\section{Implications for electrical transmission in mammalian CNS}

The functional interactions of gap junctions and glutamatergic receptors may also occur at mammalian mixed synapses, which are more prevalent than generally recognized. Using the same ultrastructural criteria for identification of neuronal elements as applied in the current study, conventional freeze-fracture studies revealed that mixed synapses are abundant throughout the rat spinal cord, comprising 3-10\% of all synapses on both interneurons and motor neurons (Rash et al., 1996, 1998).

Mixed synapses also have been identified in inferior olive, cortex, lateral vestibular nucleus, retina, and hippocampus (Sloper, 1972; Korn et al., 1973; Sotelo and Korn, 1978; Rash et al. 2000). Interestingly, the several hundred Cx35-immunofluorescent puncta distributed over the entire soma and larger dendrites of vestibulospinal and reticulospinal cells (this report) is almost identical to the several hundred mixed synapses estimated by freeze-fracture analysis of rat spinal cord neurons (Rash et al., 1996, 1998). Moreover, just as in goldfish brain, similar E-face PSDs were colocalized with gap junctions in mixed synapses in rat spinal cord, inferior olive, and retina (Rash et al., 2001), and double labeling has revealed NR1-containing PSDs and $\mathrm{Cx} 36$-containing gap junctions at mammalian mixed synapses (Rash et al., 2000b). Given the functional similarities (O’Brien et al., 1998; Srinivas et al., 1999; Al-Ubaidi et al., 2000; Teubner et al., 2000) and high degree of homology between Cx35 and Cx36 (Belluardo et al., 1999), the present data point to the possibility that activity-dependent plasticity might also occur in Cx36-mediated electrical synapses in mammals.

Because activity-driven interactions between chemical and electrical synapses at club endings seem to occur postsynaptically via PSD-mediated signaling (Pereda et al., 1998; Smith and Pereda, 2003), these interactions may not be limited to mixed synapses. In some cases, PSDs belonging to separate chemical synapses nevertheless may be situated sufficiently close to gap junction plaques in adjacent electrical synapses to alter their conductance. Recent freeze-fracture studies of retina, inferior olive, and spinal cord in rats (Rash et al., 2001) revealed E-face PSDs similar to those identified in goldfish brain, and these PSDs were found at distances from adjacent gap junctions comparable with those in goldfish mixed synapses. Such arrangements suggest that gap junction modulation by chemical transmission may constitute a widespread property of electrical synapses in mammalian $\mathrm{CNS}$ and may be relevant to CNS regions where glutamatergic transmission and gap junctions containing Cx36 coexist.

\section{References}

Al-Ubaidi MR, White TW, Ripps H, Poras I, Avner P, Gomes D, Bruzzone R (2000) Functional properties, developmental regulation, and chromosomal localization of murine connexin36, a gap-junctional protein expressed preferentially in retina and brain. J Neurosci Res 59:813-826.

Bartelmez GW (1915) Mauthner's cell and the nucleus motorius tegmenti. J Comp Neurol 25:87-128.

Belluardo N, Trovato-Salinaro A, Mudo G, Hurd YL, Condorelli DF (1999) Structure, chromosomal localization, and brain expression of human Cx36 gene. J Neurosci Res 57:740-752.

Bennett MVL (1977) Electrical transmission: a functional analysis and comparison with chemical transmission. In: Cellular biology of neurons, Vol I, Section I, Handbook of physiology. The nervous system (Kandel ER, ed), pp 357-416. Baltimore: Williams \& Wilkins.

Bennett MVL, Aljure E, Nakajima Y, Pappas GD (1963) Electrotonic junctions between teleost spinal neurons: electrophysiology and ultrastructure. Science 141:262-264.

Berman N, Dunn RJ, Maler L (2001) Function of NMDA receptors and persistent sodium channels in a feedback pathway of the electrosensory system. J Neurophysiol 86:1612-1621.

Bodian D (1937) The structure of the vertebrate synapse. A study of the axon endings on Mauthner's cell and neighboring centers in the goldfish. J Comp Neurol 1:117-160.

Bukauskas FF, Jordan K, Bukauskiene A, Bennett MV, Lampe PD, Laird DW, Verselis VK (2000) Clustering of connexin 43-enhanced green fluorescent protein gap junction channels and functional coupling in living cells. Proc Natl Acad Sci USA 97:2556-2561.

Condorelli DF, Parenti R, Spinella F, Trovato Salinaro A, Belluardo N, Cardile V, Cicirata F (1998) Cloning of a new gap junction gene (Cx36) highly expressed in mammalian brain neurons. Eur J Neurosci 10:1202-1208.

Condorelli DF, Belluardo N, Trovato-Salinaro A, Mudo G (2000) Expression of Cx36 in mammalian neurons. Brain Res Rev 32:72-85.

Deans MR, Gibson JR, Sellitto C, Connors BW, Paul DL (2001) Synchronous activity of inhibitory networks in neocortex requires electrical synapses containing connexin36. Neuron 31:477-485.

Dermietzel R, Spray DC (1993) Gap junctions in the brain: Where, what type, how many and why? Trends Neurosci 16:186-192.

Dermietzel R, Traub O, Hwang TK, Beyer E, Bennett MVL, Spray DC, Willecke K (1989) Differential expression of three gap junction proteins in developing and mature brain tissues. Proc Natl Acad Sci USA 86:10148-10152.

Dermietzel R, Hertzberg EL, Kessler JA, Spray DC (1991) Gap junctions between cultured astrocytes: immunocytochemical, molecular, and electrophysiological analysis. J Neurosci 11:1421-1432.

Fujimoto K (1995) Freeze-fracture replica electron microscopy combined with SDS digestion for cytochemical labeling of integral membrane proteins. Application to the immunogold labeling of intercellular junctional complexes. J Cell Sci 108:3443-3449.

Furshpan EJ (1964) Electrical transmission at an excitatory synapse in a vertebrate brain. Science 144:878-880.

Galarreta M, Hestrin S (1999) A network of fast-spiking cells in the neocortex connected by electrical synapses. Nature 402:72-75.

Gibson JR, Beierlein M, Connors BW (1999) Two networks of electrically coupled inhibitory neurons in neocortex. Nature 402:75-79. 
Harris KM, Landis DMD (1986) Membrane structure at synaptic junctions in area CA1 of the rat hippocampus. Neuroscience 19:857-872.

Hormuzdi SG, Pais I, LeBeau FE, Towers SK, Rozov A, Buhl EH, Whittington MA, Monyer H (2001) Impaired electrical signaling disrupts gamma frequency oscillations in connexin36-deficient mice. Neuron 31:487-495.

Korn H, Sotelo C, Crepel F (1973) Electrotonic coupling between neurons in rat lateral vestibular nucleus. Exp Brain Res 16:255-275.

Korn H, Sotelo C, Bennett MVL (1977) The lateral vestibular nucleus of the toadfish Opsanus Tau: ultrastructural and electrophysiological observations with special reference to electrotonic transmission. Neuroscience 2:851-884

Landisman CE, Long MA, Beierlein M, Deans MR, Paul DL, Connors BW (2002) Electrical synapses in the thalamic reticular nucleus. J Neurosci 22:1002-1009.

Lin JW, Faber DS (1988) Synaptic transmission mediated by single club endings on the goldfish Mauthner cell. I. Characteristics of electrotonic and chemical postsynaptic potentials. J Neurosci 8:1302-1312.

Nagy JI, Dudek FE, Rash JE (2003) Update on connexins and gap junctions in neurons and glia in the mammalian nervous system. Brain Res Rev, in press.

Nakajima Y (1974) Fine structure of the synaptic endings on the Mauthner cell of the goldfish. J Comp Neurol 156:375-402.

O'Brien J, Al-Ubaidi MR, Ripps H (1996) Connexin35: a gap-junctional protein expressed preferentially in the skate retina. Mol Biol Cell 7:233-243.

O’Brien J, Bruzzone R, White TW, Al-Ubaidi MR, Ripps H (1998) Cloning and expression of two related connexins from the perch retina define a distinct subgroup of the connexin family. J Neurosci 18:7625-7637.

Pereda A, Faber DS (1996) Activity dependent short-term plasticity of intercellular coupling. J Neurosci 16:983-992.

Pereda A, Bell T, Faber DS (1995) Retrograde synaptic communication via gap junctions coupling auditory afferents to the Mauthner cell. J Neurosci 15:5943-5955.

Pereda A, Bell T, Chang B, Czernik A, Nairn A, Soderling T, Faber DS (1998) $\mathrm{Ca}^{2+} /$ calmodulin-dependent kinase II mediates simultaneous enhancement of gap junctional conductance and glutamatergic transmission. Proc Natl Acad Sci USA 95:13272-13277.

Phillips TE, Boyne AF (1984) Liquid nitrogen-based quick freezing: experiments with bounce-free delivery of cholinergic nerve terminals to a metal surface. J Electron Microsc Tech 1:9-29.

Rash JE, Yasumura T (1999) Direct immunogold labeling of connexins and aquaporin 4 in freeze-fracture replicas of liver, brain and spinal cord: factors limiting quantitative analysis. Cell Tissue Res 296:307-321.

Rash JE, Dillman RK, Bilhartz BL, Duffy HS, Whalen LR, Yasumura T (1996) Mixed synapses discovered and mapped throughout mammalian spinal cord. Proc Natl Acad Sci USA 93:4235-4239.

Rash JE, Duffy HS, Dudek FE, Bilhartz BL, Whalen LR, Yasumura T (1997) Grid-mapped freeze-fracture analysis of gap junctions in gray and white matter of adult rat central nervous system, with evidence for a "panglial syncytium" that is not coupled to neurons. J Comp Neurol 388:265-292.

Rash JE, Yasumura T, Hudson CS, Agre P, Nielsen S (1998) Direct immunogold labeling of Aquaporin-4 in "square arrays" of astrocyte and ependymocyte plasma membranes in rat brain and spinal cord. Pro Natl Acad Sci 95:11981-11986.

Rash JE, Yasumura T, Furman CS, Ottersen OP, Pereda AE, Dudek FE, Whalen LR, Staines WA, Nagy JI (2000) Excitatory mixed synapses in goldfish and rat: freeze-fracture replica immunogold labeling of glutamate receptor NR1 and connexin36. Soc Neurosci Abstr 26:1390.

Rash JE, Yasumura T, Dudek FE, Nagy JI (2001) Cell-specific expression of connexins and evidence of restricted gap junctional coupling between glial cells and between neurons. J Neurosci 21:1983-2000.

Revel JP, Karnovsky MJ (1967) Hexagonal array of subunits in intercellular junctions of the mouse heart and liver. J Cell Biol 33:C7-C12.
Richter A, Precht W, Ozawa S (1975) Responses of neurons of lizard's, Lacerta viridis, vestibular nuclei to electrical stimulation of the ipsi- and contralateral VIIIth nerves. Pflügers Arch 355:85-94.

Robertson DJ, Bodenheomer TS, Stage D (1963) The ultrastructure of Mauthner cell synapses and nodes in goldfish brain. J Cell Biol 19:201-221.

Rovainen CM (1974) Synaptic interactions of reticulospinal neurons and nerve cells in the spinal cord of the sea lamprey. J Comp Neurol 154:207-223.

Severs NJ (1999) Cardiovascular disease. Novartis Found Symp 219:188206.

Sloper JJ (1972) Gap junctions between dendrites in the primate cortex. Brain Res 44:641-646.

Smith M, Pereda A (2003) Chemical synaptic activity modulates nearby electrical synapses. Proc Natl Acad Sci USA 100:4849-4854.

Sohl G, Degen J, Teubner B, Willecke K (1998) The murine gap junction gene connexin 36 is highly expressed in mouse retina and regulated during brain development. FEBS Lett 428:27-31.

Sotelo C, Korn H (1978) Morphological correlates of electrical and other interactions through low-resistance pathways between neurons of the vertebrate central nervous system. Int Rev Cytol 55:67-107.

Srinivas M, Rozental R, Kojima T, Dermietzel R, Mehler M, Condorelli DF, Kessler JA, Spray DC (1999) Functional properties of channels formed by the neuronal gap junction protein connexin36. J Neurosci 19:9848-9855.

Sur C, Wenthold R, Triller A (1994) Differential cellular distribution of excitatory amino acid receptor subunits on the M-cell of teleost. Soc Neurosci Abstr 20:489.

Takumi Y, Ramirez-Leon V, Laake P, Rinvik E, Ottersen OP (1999) Different modes of expression of AMPA and NMDA receptors in hippocampal synapses. Nat Neurosci 2:618-624.

Teubner B, Degen J, Sohl G, Guldenagel M, Bukauskas FF, Trexler EB, Verselis VK, De Zeeuw CI, Lee CG, Kozak CA, Petrasch-Parwez E, Dermietzel $\mathrm{R}$, Willecke K (2000) Functional expression of the murine connexin36 gene coding for a neuron-specific gap junctional protein. J Membr Biol 176:249-262.

Tuttle R, Masuko S, Nakajima Y (1986) Freeze fracture study of the large myelinated club ending synapse on the goldfish Mauthner cell: special reference to the quantitative analysis of gap junctions. J Comp Neurol 246:202-211.

Wolburg H, Kastner R, Kurz-Isler G (1983) Lack of orthogonal particle assemblies and presence of tight junctions in astrocytes of the goldfish (Carassius auratus). Cell Tissue Res 234:389-402.

Wolszon L, Pereda A, Faber DS (1997) A fast synaptic potential mediated by NMDA and non-NMDA receptors. J Neurophysiol 78:2693-2705.

Yang XD, Korn H, Faber DS (1990) Long-term potentiation of electrotonic coupling at mixed synapses. Nature 348:542-545.

Yox DP, Faber DS, Nicholson BJ (1990) Gap-junction antibody attenuates electrical coupling between the goldfish Mauthner (M-) cell and its eighth nerve afferents. Soc Neurosci Abstr 16:185.

Zottoli SJ, Danielson PD (1989) The lateral line afferent and efferent systems of the goldfish with special reference to the Mauthner cell. In: The mechanosensory lateral line: neurobiology and evolution (Coombs S, Görner P, Münz H, eds), pp 461-478. New York: Springer.

Zottoli SJ, Faber DS (1979) Properties and distribution of anterior VIIIth nerve excitatory inputs to the goldfish Mauthner cell. Brain Res 174:319-323.

Zottoli SJ, Van Horne C (1983) Posterior lateral line afferent and efferent pathways within the central nervous system of the goldfish with special reference to the Mauthner cell. J Comp Neurol 219:100-111.

Zottoli SJ, Bentley AP, Prendergast BJ, Rieff HI (1995) Comparative studies on the Mauthner cell of teleost fish in relation to sensory input. Brain Behav Evol 46:151-164. 